\title{
CONTRIBUTIONS TO THE HERPETOLOGY OF POR'YO RICO
}

\section{By Kinr P’attemson Schmitr}

As a part of the Scientific: Survey of Porto Rico inilugurated by the New York Acalemy of Sciences nnil curriel on with the coüperation of The American Museum of Natural History and other institutions, it wats my good fortune to conduct the first herpetological field-work in the summer of 1919. For this purpose Mrs. Schmilt and I spent the period from August 3 to October 3 on P'orto Rico and the adjacent islands, which are under the same political jurisdiction.

For cordial assistance in furthering our work, I am especially grateful to Mr. and Mrs. B. A. Wall, of San Juan; Mr. E. MI. Bruner, Forester of Porto Rico; Mr. Mare Lejeune, of Mayaguez, who made possible the trip to Mona Island, and to Colonel George A. Shrnton, Chicf of the Insular Police.

The exceptionally thorough and exhaustive "Herpetology of Porto Rico" by Dr. Leonhard Stejneger is available as a handbook of the reptiles and amphibians, making it possible to identify the species in the field and thus facilitating the sturly of liabits and hahitat associations. Dr. Stejneger has given an excellent résuné of herpetological work on Porto Rico previous to his own. The herpetological papers which have appeared since 1902 relating to the fauna under consideration are given in the bibliography at the close of this paper.

Collections were made on the islands of Porto Rico, Mona, Vieques and Culebra. Notes on the relation between the clistribution of the species and the types of habitat will be found helow under the discussion of individual species. The addition of six species of Fleutherodactylus to the Porto Rican fauna, five of which are here described as new, is an unexpecterl result of the expedition. All but one of these were captured with the aid of an electric hand-lamp while they were singing at night. This methorl of stalking is well known to those who have studied the notes of amphibians. The voices of Eleutheroulactylus, as of ather frogs and toads, are useful characters for distinguishing the speries.

The expedition secured over twelve liundred specimens, comprising thirty-one species. To this collection are added more than a hundred specimens obtained by previous cxpecititions of the survey (II. L. Anthony, 'T. H. Jones, F. E. Lutz, R. W. Miner, J. 'T. Nictols), makinur the total 
number of specinens, on which this report is based, much larger than any previously made in Porto Rico and equaling in completeness that of the National Museum.

The present paper is preliminary' to the general account of the herpetology of Porto Ricn to be published by the New York Academy of Sciences in the. volumes embolying the results of the Scientific Survey of Porto Rico and the Virgin Islands.

\section{AMPHIBIA \\ Bufo Laurenti \\ Bufo lemur (Cope)}

This species, five specimens of which were collected at Coamo Springs, has previously been known from the north side of Porto Rico; the only exact locality being given as Arecibo by Stejneger. Its occurrence at Coamo Springs, nearly at the opposite side of the island, proves that it is widely distributed.

The five half-grown specimens are so nearly uniform and were found in so circumscribed an area that they probably are members of a single brood. They agree in coloration with the juvenile specimen described by Stejneger (1904, p. 572) and all show the hour-glass shaped dark mark on the shoulders. The dimensions of one of these specimens may be compared with those of an adult recorded by Stejneger:

\begin{tabular}{|c|c|c|}
\hline & $\begin{array}{l}\text { A. M. N. H. } \\
\text { No. } 10151\end{array}$ & $\underset{\text { No, }}{\text { U. S. Nits }}$ \\
\hline Tip of snout to vent. & $37 \mathrm{~mm}$. & $8.3 \mathrm{~mm}$. \\
\hline of snout to posterior edge of tympanum....... & $12 \cdots$ & ?ח) \\
\hline Greatest width of head.. & 13 “ & .22 “ \\
\hline Foreleg from axilla $\ldots \ldots \ldots \ldots \ldots \ldots$ & $21 " \cdots$ & $51 "$ \\
\hline Hind leg from vent. & $37 "$ & 99 \\
\hline
\end{tabular}

The stomach contents of these specimens included ant remains, beetle wings, an insect larva, and segments of a small millipede.

\section{Leptodactylus Fitzinger}

\section{Leptodactylus albilabris (Günther)}

The following localities are represented by sixty-three specimens in the collections: Adjuntas, Aibonito, Bayamon, Caguas, Coamo Springs, Marican, San Turce, Utuado, El Yunque, and Culebra Island.

This species exhibits a great variability in coloration, with a relative uniformity in structural characters. Fowler (1918, p. 3, Fig. 1) has 
figured the extremes of color pattern in Porto Rican specimens. Of fifty specimens in the present series, seven have the broad median stripe on the back, the others varying chiefly in the distinctness of the doreal V. shaped markings. The measurements of the largest specimen and of one apparently recently transformed are as follows:

\begin{tabular}{|c|c|c|c|c|}
\hline \multirow{3}{*}{ 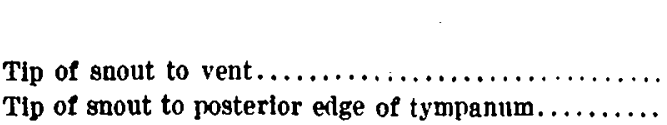 } & \multicolumn{4}{|c|}{ No. 10182 M. N. 吕. } \\
\hline & $\begin{array}{r}\text { No. } \\
49 \mathrm{n}\end{array}$ & & & \\
\hline & 18 & “ & $\mathbf{7 . 5}$ & * \\
\hline Greatest width of head... & 17 & " & 7 & " \\
\hline Foreleg from axilla........ & 29 & " & 10 & " \\
\hline Hind leg from vent to tip of longest toe & 78 & “ & 24 & “6 \\
\hline
\end{tabular}

Eight of twenty-five stomachs examined were empty. Four contained land snails; two contained spiders (one a large lycosid spider and egg sack); two contained ants; two contained beetles; two contained bugs; two contained flies (Muscidæ); one a small moth; one a large caterpillar; one a medium-sized cockroach; and seven the remains of an unidentifiable insect.

The nest of this species was observed by Stejneger $(1904$, p. 579) under a flat stone in a stream. Peters (1877, Monatsber. Akad. Wiss. Berlin, 1876, p. 709) records one observed by Gundlach in a "wet burrow." At Coamo Springs, on the terrace behind the bath-houses of the hotel, the water of some of the springs forms a permanent rivulet at the base of the cliff. Leptodactylus albilabris was abundant on the terrace, beneath loose stones. Under a large stone at the edge of the creek, on August $27,1919, \mathrm{I}$ found a shallow, rounded excavation, 6 or $7 \mathrm{~cm}$. in diameter and about $3 \mathrm{~cm}$. deep, filled with a mass of white foam, in which were the small tadpoles of this species $(12 \mathrm{~mm}$. in length, body $3-4 \mathrm{~mm}$.). There were between serenty-five and one hundred tadpoles in the foam-mass, and not confined to the central hollow, as described by Stejneger. The bottom of the excavation was about $3 \mathrm{~cm}$. above the water level. Two similar excavations, though empty, were discovered in the immediate vicinity, in the same relative position with reference to the water. On August 29, near Bayamon, a small mass of foam, between 3 and $4 \mathrm{~cm}$. in diameter, containing similar tadpoles, was found under a stone on a hilltop, with no water whatever in the neighborhood. On October 1, near the Forester's cabin, on El Yunque, at about 1200 feet, a nest of this species was observed under a rotten log, heside a pool of standing water (also at a slightly higher level than that of the water). This nest contained between 150 and 200 eggs uniformly distributed

I 144 mm.' given by Stejneger (1004, pp. 570, 57S), is obvlously a mleptint. 


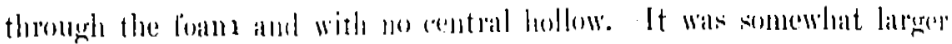

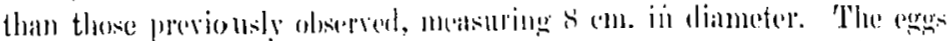

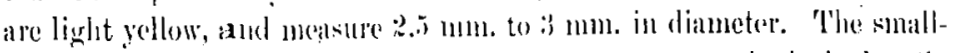

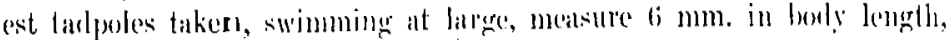

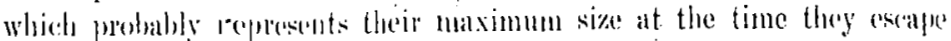

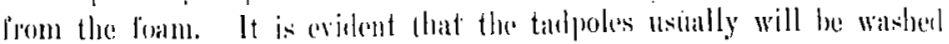

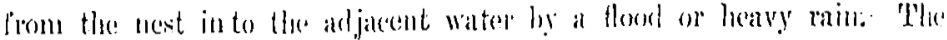
small nest isolated from water was probubly a mistake on the part of the

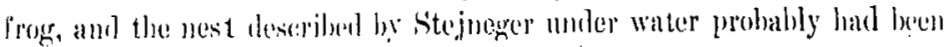
covered by a rise in the areck after the deposition of the egress. The larerest larve, nearly ready to tramsform, mensure $13 \mathrm{~mm}$. from shont to rent. The V-sha ped dorsal markings ate already crident in the tardpolew at this stage. 'The meslian dorsal white line is probably' an nolut character.

\section{Eleutherodactylus Dumerril and Bibron}

\section{Eleutherodactylus auriculatus (Cope)}

The following localities are represented by two humled and seven specimens in the collection: Idluntas, Aibonito, Alto Manzano, Catano,

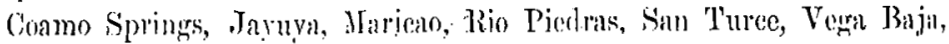
and Eil Yunque. Ellentherndactylus auriculatus oceurs in Santo Domingo and ('nlan as well as in Porto lien, the type bocility being Culn. It appears to be rare in (uba and Sianto Domingo, while in Porto Rico it is

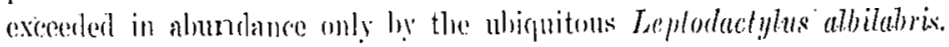
lts closest relative appents to be the k'. marlinicensis of the Lusser Antilles.

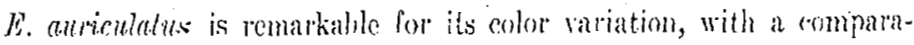
tively stable structure, but a consirlerable rariation in measurements.: al specimen in the collection of Prof. (4. F. Johnson, af the Tuiversity of

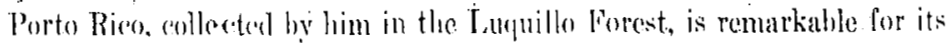

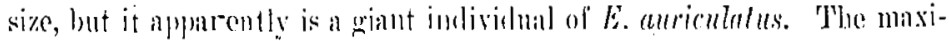
num size in over there hubdred sperimens in the National Mruscum and

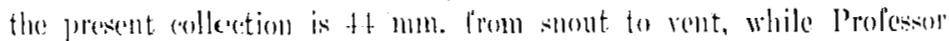

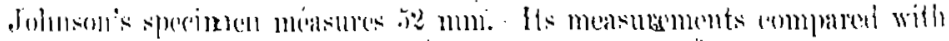

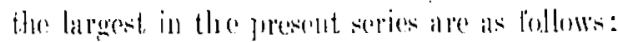

\begin{tabular}{|c|c|c|}
\hline & & \\
\hline rijo of silol & No. $102+1$ & 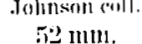 \\
\hline . & $18 \cdot$ & $\because \underbrace{\prime}$ \\
\hline 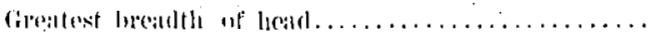 & $19 \cdots$ & 范 “ \\
\hline rom in illa & " & " י יו: \\
\hline Illad bue from vent & (6!) “" & (s) “ " \\
\hline
\end{tabular}




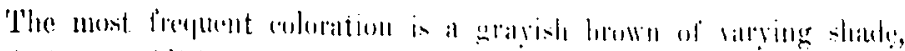

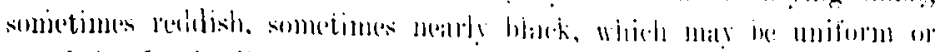

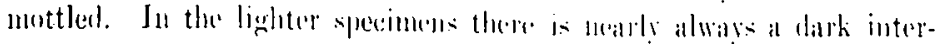

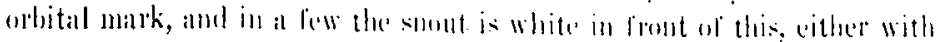

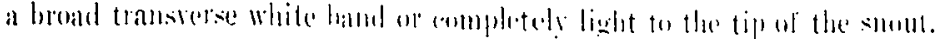

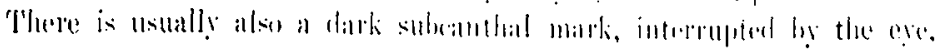

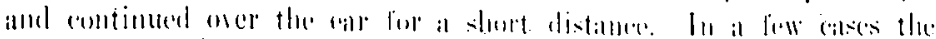

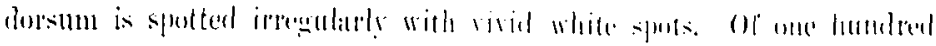

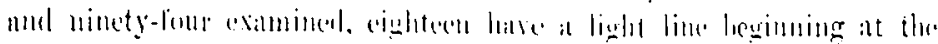

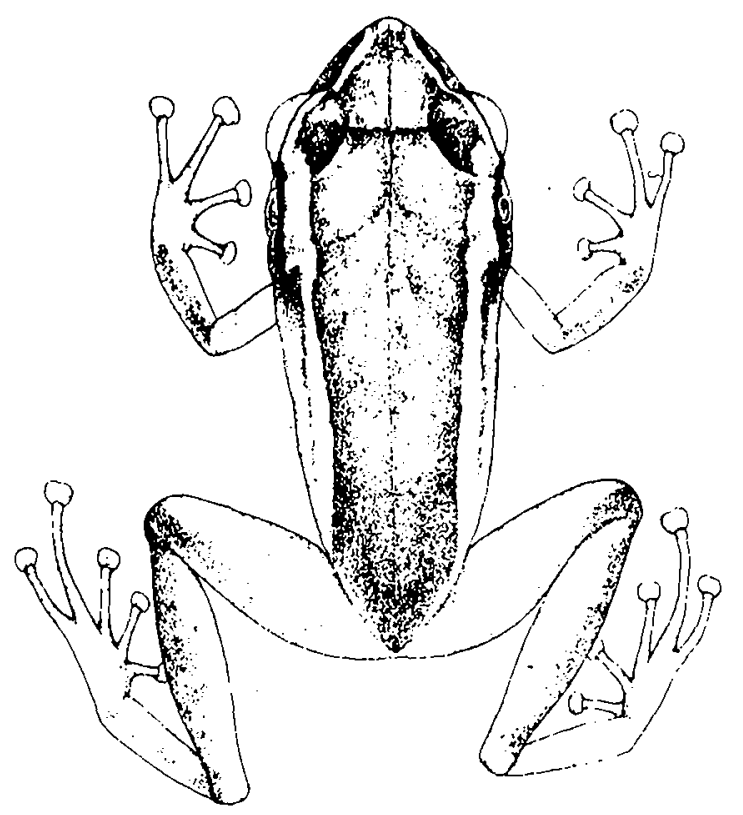

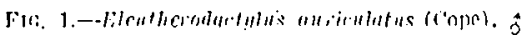

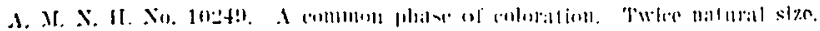

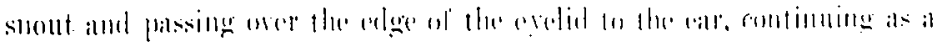

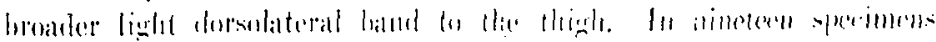

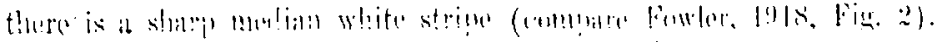

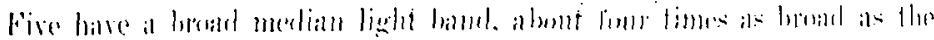

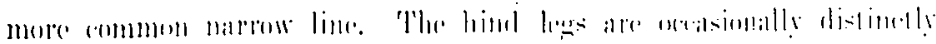

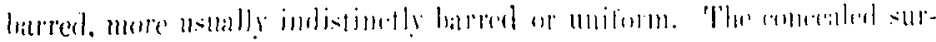

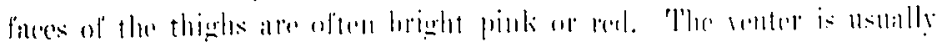

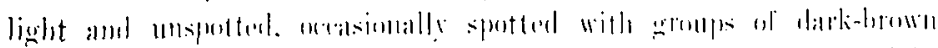

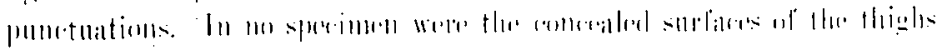

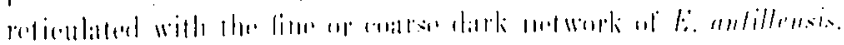


Persistent search about the banana plants, under the lesves of which adults hide during the day, failed to discover the eggs of this species, and it was not until the writer visited the I,uquillo Forest that a single: egg-mass was discovered in a basal leaf of an air plant, just at the surface of the water in the lower part of the leaf. A large E. auriculalus in the same plant, but not on the same leaf as the egers, escaped. There are thirty-six eggs, with well-advanced cnibryos, adhering in an oval mass, from which individual eggs are easily detached. The eggs measure 6-8 mm. in greatest diameter, being somewhat elongated in the axis of the embryo.

The young of this species are extrnordinarily abundant, and it is difficult to understand why the eggs are so infrequently ohserved. It is possible that at the time of my visit (August to Oetober) the height of

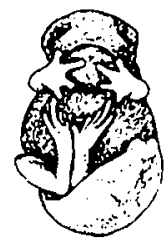

Fir: ".-Inibryo of Elcuthern. anctulus anviculatus

A. M. N. II. No. 10302. Four tlmes naturnl slar. the breeding season had passed. The only previously recorded date of brecling is that observed by Gundlach, May 24 (Peters, 187\%, Monatslber. Akad. Wiss. Berlin, 18\%6, p. 609). P'rofessor Johnson found a mass of cogrs on July 8, with emlnryos at about the same stage as the writer's, in the same bunch of moss in which the giant female specimen, mentioned above, was collected. Gundlach (loc. cit.) also observed a female sitting on the egg-mass received by him, while Bello y Espinosa (Martens, 18i1, \%oül. Garten, XII, p. 351) records that in the casc observed by him the parent frog remained in the neighborlood of the egros "as if to gutirl them." From these several olservations it appears not unlikely that the fenale lues remain in the neighthorhood of the exgs until they are hateled, but further ubervations on this point are desinahle. Ruthren (1015, Occas. Papers, Mlus. Zoül. Univ. Michigan, No. 11), observiugr the breeding habits of he crumulus.s (l'eters) in Colombial, found no cridenee of such a habit.

\section{Eleutherodactylus gryllus, new speries}

Sixtecn specimens from Maricao and Fil Yonque were collected.

\section{Jiugnostic Characters}

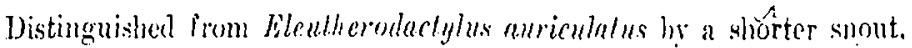
less granulate venter, and its minnte size. 


\section{liange}

'l'aken at bl Yuncue and Marican, molably confined to the coffee belt nnd the wet rain forests above it.

T'y

A. II. ․ II. No. 1030\%, of, El Yumpue, near the Forester's culin (atont 1300 lect), Scptember 30, 191!), Karl 1'. Schmidt.

\section{Description of Type}

Habitus of Elentherodactylus auriculatus, but with a distinctly shorter snout, its length equal to the diameter of the eye (in $E$. auriculatus the diameter of the eye equils its distance Irom the nostril), and to the interorbital space; ennthus rostralis rounded; nostril one-third the dis-

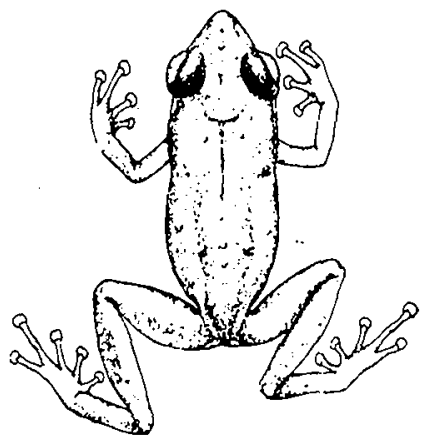

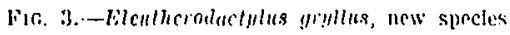

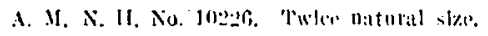

tance from tip of shout to eye; tymlamum scallecly distinct, onc-fourti the diameter of the eye, its distance from the eye expal to its diameter; toes without vestige of weh; digital disks well dewelopen ; first toe as long as the scond; an inner an! onter metatarsal lolle romerinc teeth in two ohlique patehes behind and within the choana!; tongue latge. slightity nicked behind; skin smooth abuve, but apparently much more glandalar

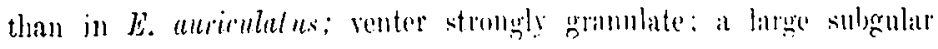
vocal sac.

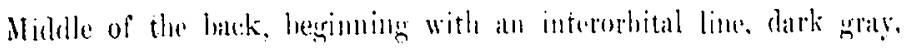

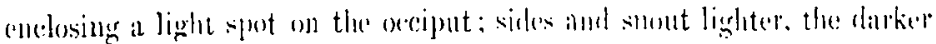

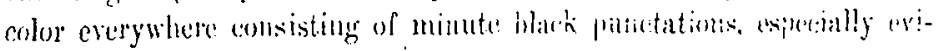
dent on the limbs and throut; vinter bight. 
Mrestiriments

Tip of shout to rint $\ldots \ldots \ldots \ldots \ldots \ldots \ldots \ldots \ldots \ldots \ldots \ldots \ldots \ldots$ 1; m.

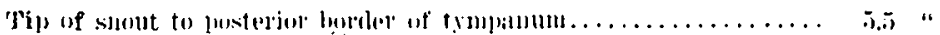

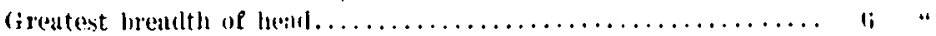

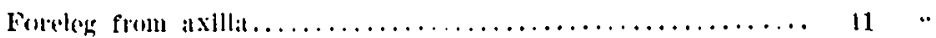

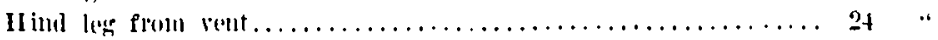

Tibia............. "

Noles on Preralypess

'The type is a male. taking singing at nigrat, with the msual pale night coluration. Sijerimens taken in the daytime (concealed under moss) are very dark in color and exhibit comsiderable rariation in pattern, two having a light melian dorsal line. In a specimen taken in a: air plant (No. 10291) the dorsal dart area is cimmumon brown and the sildes bright pale green, the legs with dark bars; this colomion lans been described by

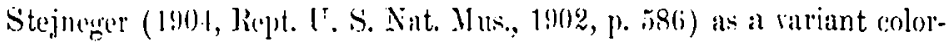
ation ol' jurenile k. amricululus. 'The rauker specinens have narrow light

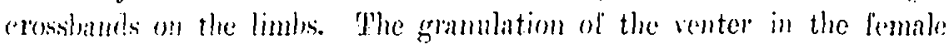
sperimens is laint, though still evident.

'l'his species was found rery numerons at Marican and on El Yungue, singing brequently from trees, at hast ten fect from the gromal. On El Yunque specimens were collected in air plants, near the peak, and nuder moss on the "octes of the peak itself.

The note is a rapicl succession of shrill clicks, very insect-like; the (:hocus sounding nut unlike the rapid elicking of a telegraphic instrument.

Nere it not lor the minute size of the singers and the extremely dis-

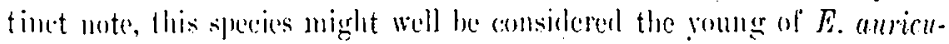

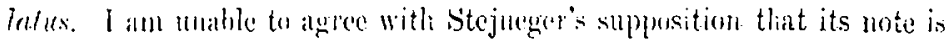

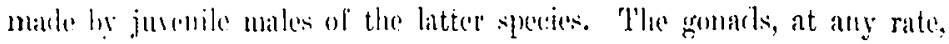

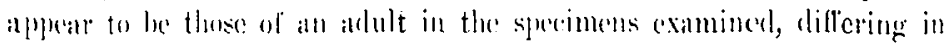

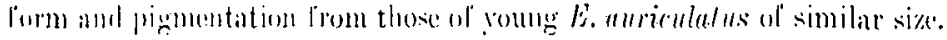

\section{Eleutherodactylus locustus, new spereies}

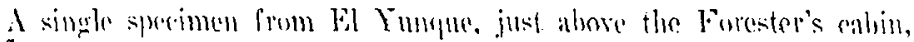
roillected sipstember :311, 1!999.

\section{Jingunoslir: ('houacters.}

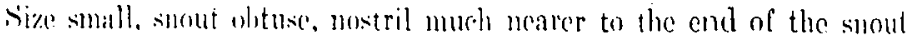
than to the eye: tympanmm small, inlistinct, ome-fourth the diameter of

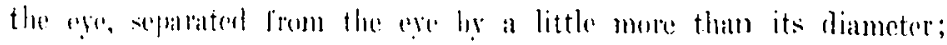




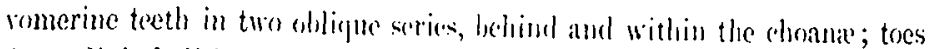

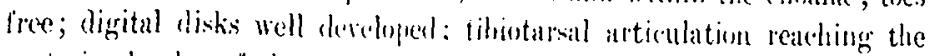

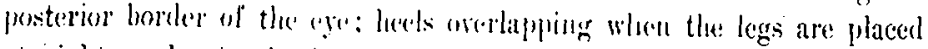
at right angles to the louly; skin rogose above, with seattered round tubereles, esperially on the crediel: venter smunth; inner face of thights finely rugeses.

\section{liange}

Kinown only from the type lonality.

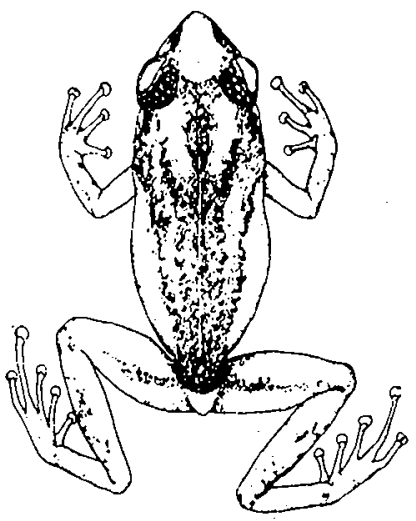

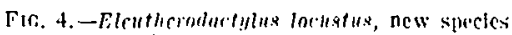

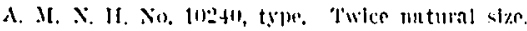

Ty/pe

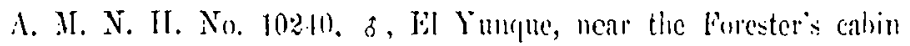

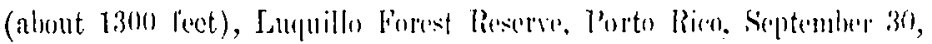
1!)!9, Karl 1'. Aichmirlt.

\section{Descriplion of $7 y /{ }^{\prime}$}

Thad slightly longer than broad, slightly natrower than the body: snout molerately obtuse, its lenerth anterion to the eye exceceling the interorbital space; nostrils one-fourth the distance: between eye and tip of snont from the latter" trimpanum searecly distincet, one-lourth the diameter of the eye, sejarated lrom the eye he al lithe more than its

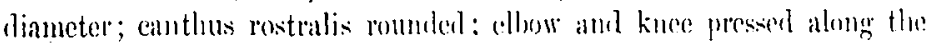

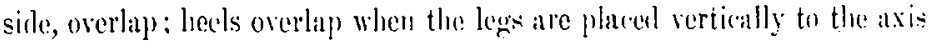
of the boly; libiotarsal articulation reating the posterion loveler of the

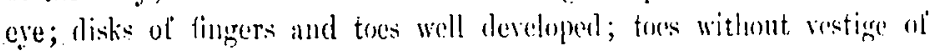


web) inner and outer metntarsal tulureles present; no tarsal fold; first toe as long as the second ; vomerine teetl in two linear oblique putches, converging posteriorly, well separated on the median line, behind and within the choane by about the diameter of the chomin; tongue lares, slightly nicked behind; skin rugose above, with rourded tubereles; a wellmarked mid-rlorsal ridge from snout to vent; cyclid strongly rugose; venter smooth (luintly rugose under the lens); thighs slightly rugesse; male with a large subgular rocal sac.

Dorsum gray, mottled with grayish brown; al well-defined interorbital dark band; sides of cantlus with a dark mark, interrupted by the eye, cxtending over the tympanum, legs not barred, with dusky markings; venter uniform, light.

\section{Jeusurements}

Tip of snout to vint $\ldots \ldots \ldots \ldots \ldots \ldots \ldots \ldots \ldots \ldots \ldots \ldots \ldots \ldots \ldots .19 \quad \mathrm{~mm}$.

Tip of snout to posterior borter of tympanum........

Greatest breadth of hend......................... 6.5 ."

Foreleg from axilla.......................... 12 "

Hind leg from vent. $\ldots \ldots \ldots \ldots \ldots \ldots \ldots \ldots \ldots \ldots \ldots \ldots \ldots$, gI

'libia.

This specics was discovered by aceident, singing on a leaf some three feet from the ground. Its note is the most distinctive of any observed in Porto Rico, beginning with a shrill continuous note almost at the limit of audibility, which is followed by a succession of clicks. So closely does this note resemble a familiar type of note produeed by long-horned grasshoppers that the writer negrlected to search for the author of the somd, and watched the prisent specimen lepeat the song several times before being convineed thit it really proceded from sin kileullerodactylus.

It is closcly related to h. anriculatus, from which it is well distingruished by its small size anr? smooth venter. Even more clowely related to the still smaller new species, $F$. gryllus, it is still readily distinguisherl by its smooth venter and more rugose dorsum, as well as by its somg.

\section{Eleutherodactylus cramptoni," Hew species}

Three specimens from the penk of Jil Yunguk, Suptember 30, 1919.

\section{Diaynostic Characlers}

Size small, habitus stout; hind legss short; smout rery olstuse, canthus rostralis ronder! clorsum very rugrose with romelerl tubereles; vomerine

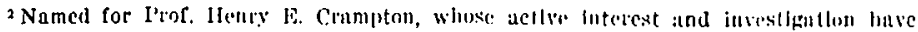
frently Purthered the zoülnglitl work of the survey.
} 
teeth in two oblique linenr series, cxtendling laterally as far as the inner border of the choana:; digital distis large; uniform dark brown above, light brown beneath.

\section{Range}

Known only from the type locality.

\section{Type}

A. M. N. H. No. 1030i, o, peak of Fl Yunque, September 30, 1919, Karl P. Schmidt.

\section{Description of Type}

Habitus stout, compact; snout short, obtusc, canthus rostralis rounded; nostril one-third the distance from tip of snout to eye; heel reaching the anterior border of the orbit; heels meet but do not overlap when the legs

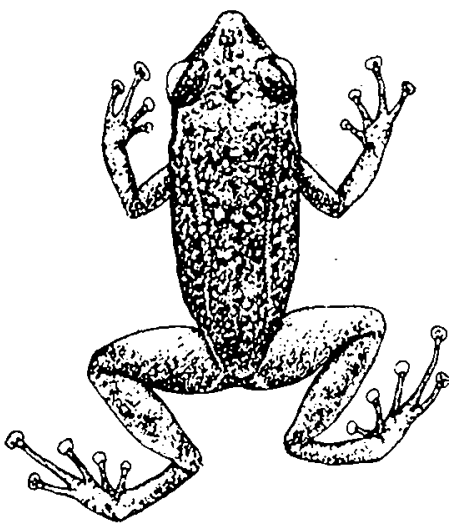

Fici. 5.-Flentherodactylus cramptoni, new specles

A. M. X. Il. No. 1030.i, type. I'kice natural slze.

are placed at right angles to the body; both anterior and posterior limbs notably stout, nearly twice as thick as those of $L$. auriculalus of the sime bodly. length; vomerine tecth in two linear, obligue series, extending laterally as far as the chonna ; tympanum small, distinct: dorsum concred with rounded tubereles, extending onto the eyelicls and surout; renter

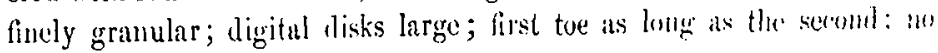
sulurular vocal sac.

Color nniform brown ahove; Jighter brown below and slightly ariegated with lighter punctations. 


\section{Mensurementuts}

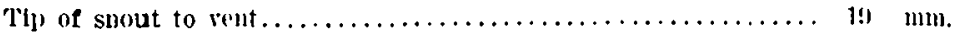

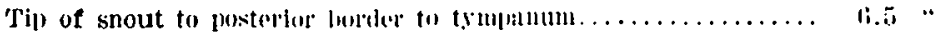

ligentest breudth of hend......................

Foleleg from axtlla...........................

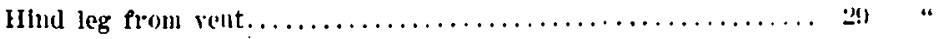

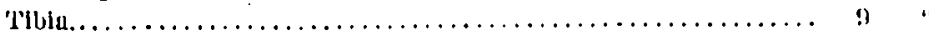

Notes on Paralypres

The two parntyjes are similar in crery respert to the type, with the single exeeption that one of them is slightly more motticel with light and lans the hind legs indistinctly barret.

'The three small tree l'roess described above were taken under moss in the crevices of the rocks on the peat of El Yunque. The species is a welldifferentiated one, characterizel by the stoutness of its limbs, the obtuseness of the slont, and the extreme rugusity of the clorsum.

\section{Eleutherodactylus antillensis (Reiuhardt and Luetkon)}

The following localities are represented by thirty specimens in the collection: Aibonito, Baymmon, Marican, San Turce, and Culchra Island. This species has previuusly loeen known only from St. Thomas (type

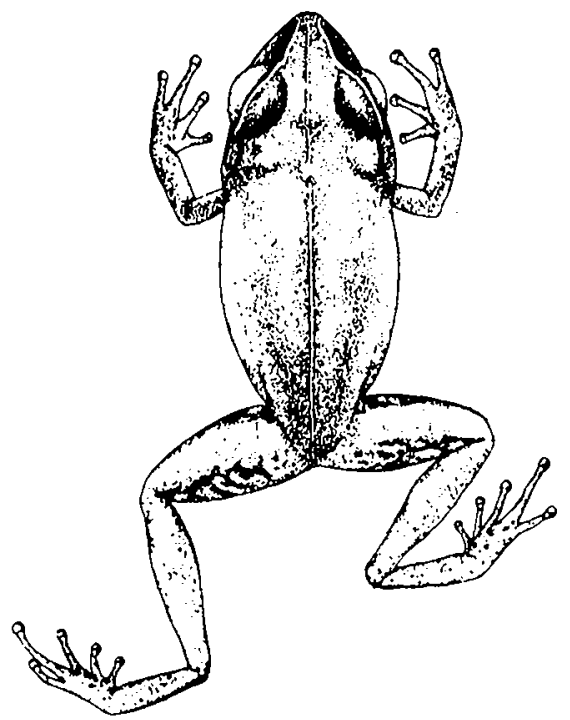

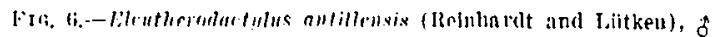

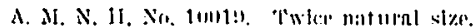




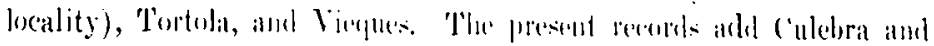

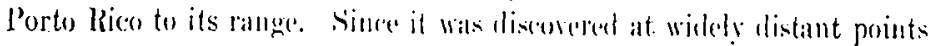

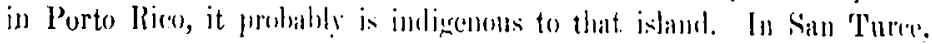

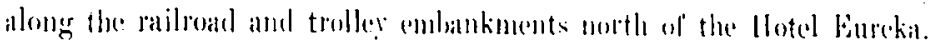

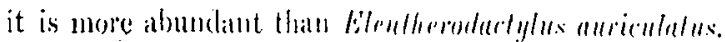

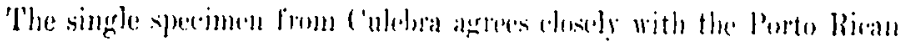

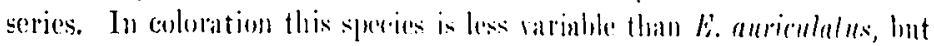
the median white dorsal lime mial he present or alsiont. It is developed

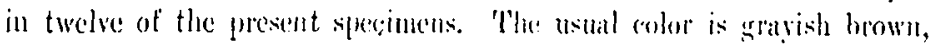
with faint dusky markings, and a sharply defined blark cantlual lime which extends over the car and a short distance beyous it, ontlined above in most eases by a very matrow white line on the canthus cextending over the eyelid. 'l'he comeciled surfires of the leass ane retienlated with black. which afforels a laidy gool character lor distinguishing this species in

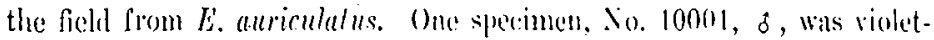
red above, with a rery heary black canthal and supra-auricular mark, and with the concealed surlaces or the lese hlanek with shamply defincel white spots. When ampared direotly with li. auriculales, this species

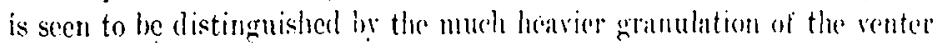
and the much smaller digrital distse in adlition to the dilierence in proportions noter by Stejneger. The measurements of the langest specimens of ench sex follow:

\begin{tabular}{|c|c|c|}
\hline & 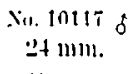 & 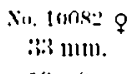 \\
\hline 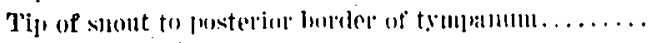 & $10 *$ & $1: 1 \%$ \\
\hline (rivil................ & $11 \%$ & $14 "$ \\
\hline$\ldots \ldots \ldots \ldots \ldots \ldots$ & $16 ; " \cdot$ & $1 ! 1 \quad \cdot$ \\
\hline II leg froull & " י & 45 \\
\hline
\end{tabular}

Eleutherodactylus brittoni," new species

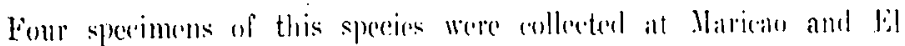
Yunque, near the forester's cabiul.

\section{Dierguastic characters}

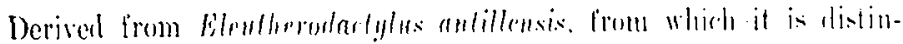

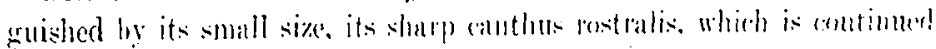

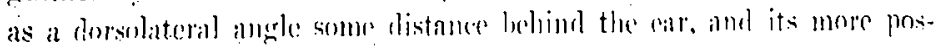
toriorly placed nostril.

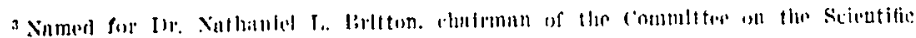

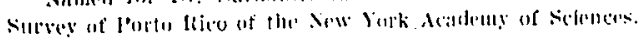


Kange

Known from Maricao and El Yunque, it is probably confined to the coffec belt and the moist forests alove it.

\section{Type}

A. M. N. H. No. 10:31s, o, El Yunque, near the Forester's caliu (about 1300 fect), September 30, 19.19, Karl P. Schmidt.

\section{Description of Type}

IIabitus slender, head narrower than the body, legs rather short, snout sharp, pointed; nostril two-fifths the distance from the end of the snout to the orbit; canthus rostralis sharp; interorbital space broarler than the

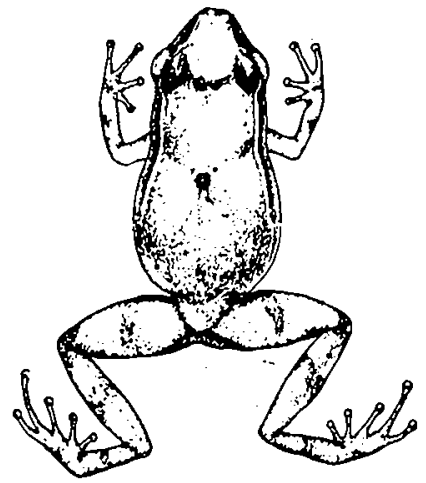

Fic. 7.-Elenthcrolactylus brittoni, now specles

A. M. N. H. No. 10318, type. Twice natural size.

eyelid; heel reaching the anterior borter of the orbit; heels meeting but not overlapping when the legs are at right angles to the body; top of snout flat, as is the anterior half of the back behind the eyes, the side of the bolly being verticnl anteriorly; vomerine teeth in two small rounder patches, bchind aml within the choana; tympanum indistinct, separated from the eye by loss than its diameter; dorsum smooth, venter coarsely granulate; digital disks small, as long as wide; a well-defined tarsal fold; a well-cleveloped suhgular vocal sac. Dorsum light grayish brown, venter lighter. 'Two black spots between the eyes, one on the middle of the back, and three posterioriy on the back, above the groin; legs with a. single faint darker bar on the femur; concealed surfaces of the femur not reticulated; a black subcanthal strcak, continued below the dorsolateral angle behind the eye. 
Tip of suout to rent............................... 16 min.

'Tip of snout to pasterior lowiler of tympanum, ..............

Greatest brealth of heatl........................... if

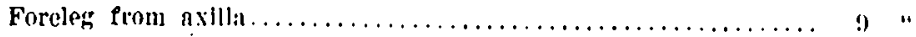

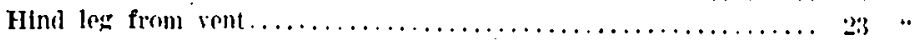

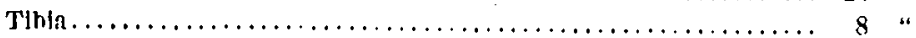

Notes on Praralypes

'The three paratypes are closely similar in size and structural characters to the type. 'T'wo have the black sulseanthal and shoulder mark outlined with white above. One lacks the dorsal hlack spots.

The specimen from Maricao was taken singing in herbage along the roadside, together with E'. auriculatus and $E$. anlillensis. 'Two were taken singing on El Yunque, likewise in low herbage, and the last was fouml ly accirlent in collecting $E$. wightmmor.

The note of this species is a suceesion of edicks, less shrill and less rapid than in li. gryllus.

This species stands in the same relation to E. antillensis as E. gryllues docs to E. auriculatus.

\section{Eleutherodactylus wightmanæ, now species}

'Thirteen specimens of this speeies were collected at Maricao and Fil Yunque, near the Forester's cabin.

\section{Dingnostic Chararters}

Size small, smout pointed; mostril sn:ch nearer to the tip of the snont than to the eyc; tympanun small, distinct, separated from the cye by about its own diancter; vomerine tecth in two straight serics, in the sane line, cxtending as far laterally as the chonure, and about the diameter of a choana belinel them: toos free, digrital dislis well developel: tibiotarsal articulation readieng the anterior lorder af the eye; licels overlapping when the lews are placed at right alloges to the borly: slin

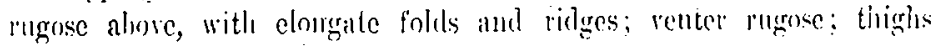
gramular.

\section{Range}

languillo Forest to Marican, probihly comfined to the coffee belt and the wet forests above it.

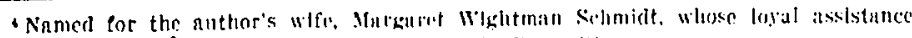
contributecl largely to the succers of the work in l'orto klico.
} 
II!l!"

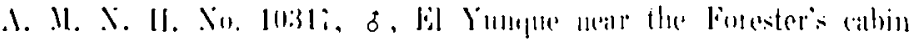

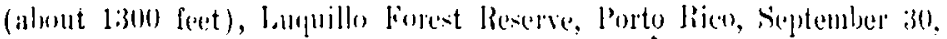
1!)1!, Karl L'. Sc.lminll.

\section{Hescriplion of t't/pe}

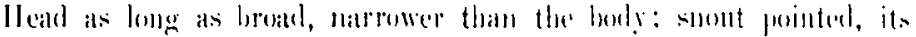
length anterior to the eyes onee and a hall the interorbital winth: nestrils one-thirel the distanese between aye amel tip of snont frous the latter: tympanum distimet, small, alout one-flid the dianceter of the ere, separated from the cye by a little more tham its own cliameter: (anthus rostralis sharp; cllow and linee pressed along sides overlap; heels overlay, when the legs are placel at right angrles to the body:

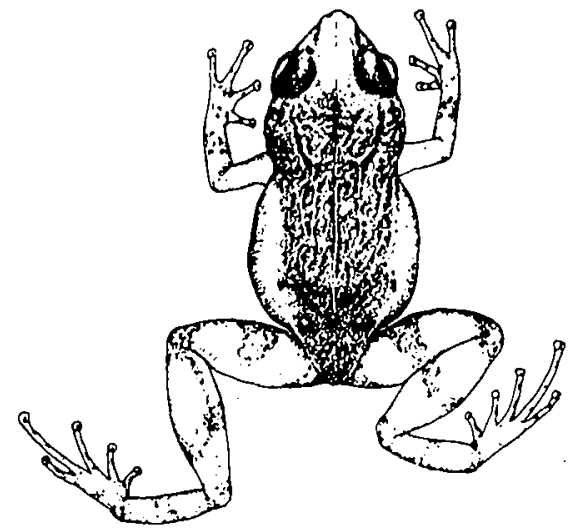

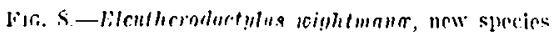

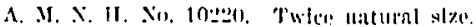

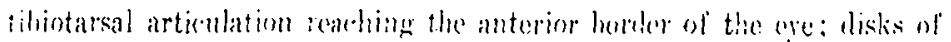

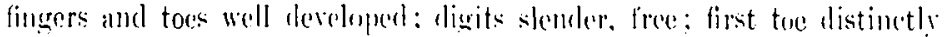
siorter than the second ; no tarsal lobls:; romerine teeth in two straight series, separaterl in the meelian line. extending laterally as lat as the

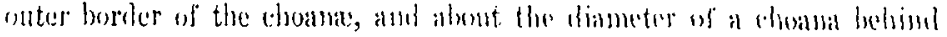

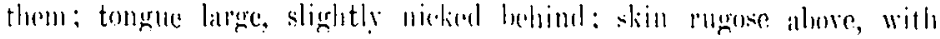
longitudinal lines or folds, the most distinct of which originate behind

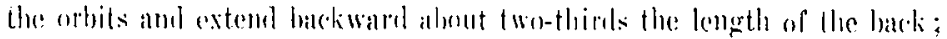

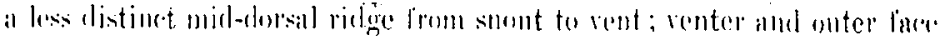
of thights ragowe; a subgrular vecal sale. 


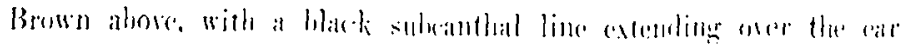

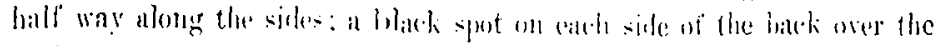

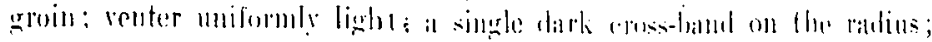

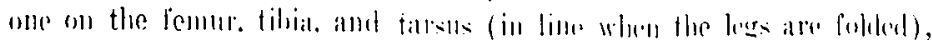

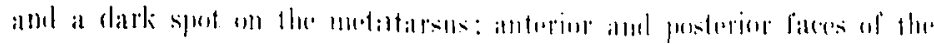
dughlis duskiy.

Herturumente

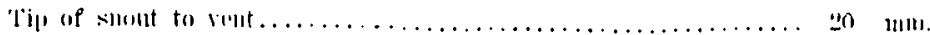

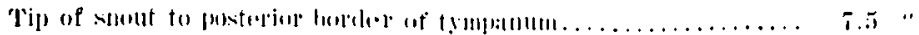

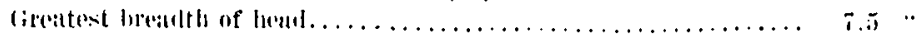

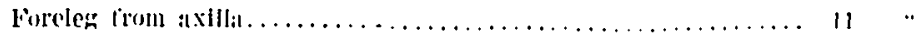

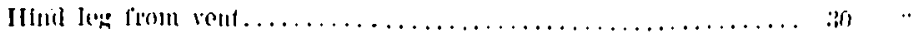

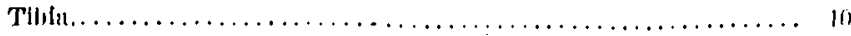

\section{Voles an P'araly}

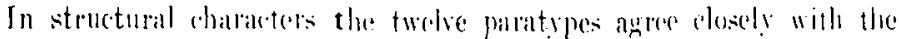

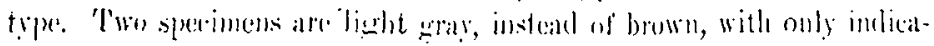

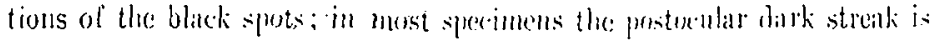
broken up into a series of spots: one sperimen is light hombing gray on

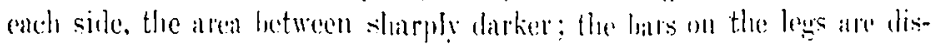
tinct in all sperimens.

The plaintive, rimimoments note of this small sperese is one of the

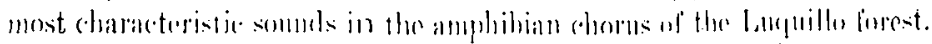

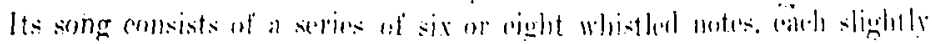

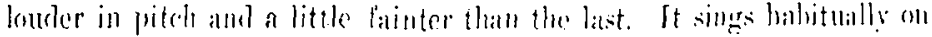

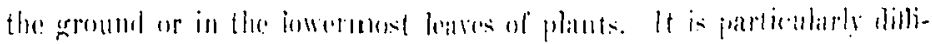

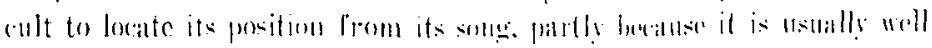

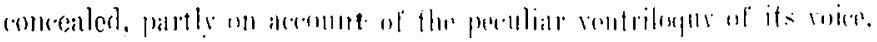

\section{Eleutherodactylus richmondi Str.jum}

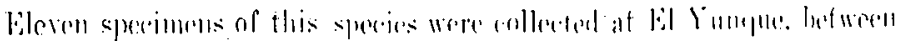

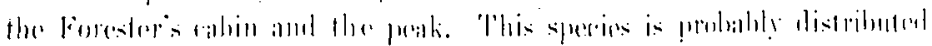

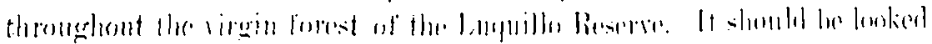

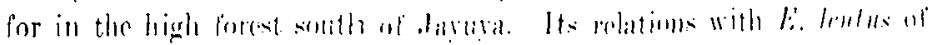

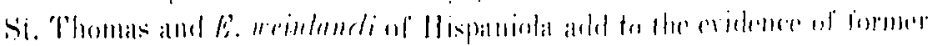

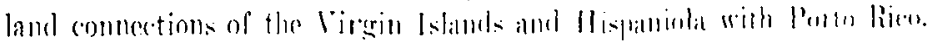

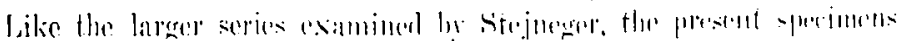

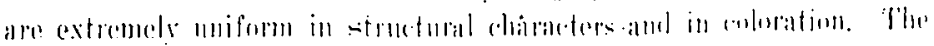

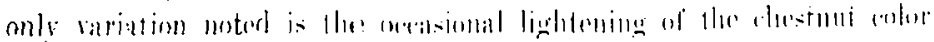

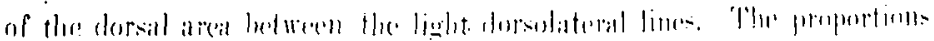


are quite different in this species from the other Porto lican sper. îes of the genus:

. $x_{0}, 10 \pm 33$

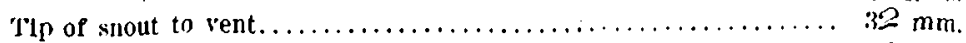

Tip of snout to posterior horder of tymbinmm.............. 1; ."

Greatest breadth of heith........................ is

Foreleg from axillı............................. 21 “

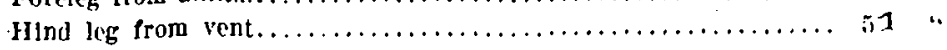

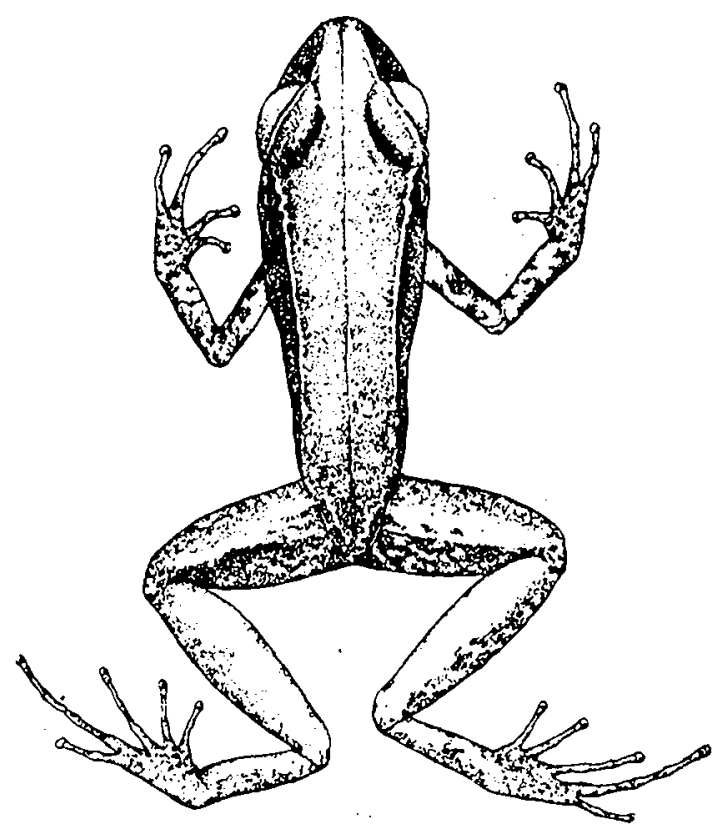

Fug. ?.-Elculherodactylus richmondi Stejneger

A. M. N. H. No. 10237. 'Twice natural size.

Two extremely small specimens, measuring 9 and 11 min. respectively, probahly are recently transformed. They are colneed like the adu lts.

\section{REPTIISIA}

\section{Sphærodactylug Wagler}

\section{Sphærodactylus macrolepis Giinther}

Spheroductylus macrolepis monensis Meerwarth, 1:01, Mitt. Naturh. Mus. Hawburg. XVIII, p. 20.

Sphrrodact/lus monensis Stejneger, 1904, Rept. U. S. Nut. Mus., 1:02, n. 607 . Barhour, 19t4, Mem. Mus. Comp. Zoöl., XLIY, n. 2 m. 


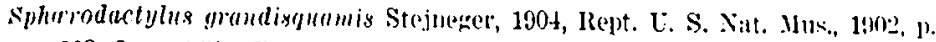

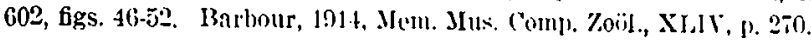

The followius localities are represented by lorty-fire sperimens in the

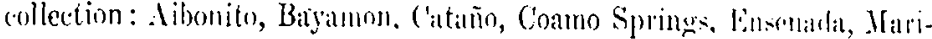
can, El Yunculue, and Mona Island. 'Tlis species is found on Momil Islannl, througlont l'orto Rico, and on most of the Vircrin Islands (Vierpes, St.

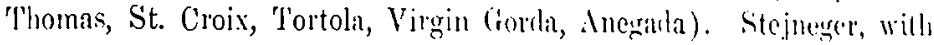
specimens from only two localities in l'orte) Tico (Tuguillo and Poncel. describer the Porto Riean and Vierues specimens as distiunt irom the Virgin Island form, as well as from that of Woun Islanrl. He sllmined that it was confined to the lowlands, whereas the presont series proves that it reaches an altitude of at least two thousind loot.

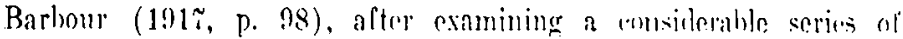

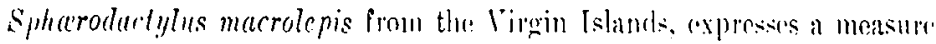

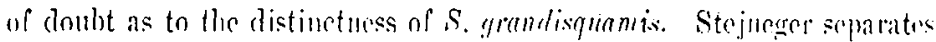
S. grandisquamis and S. monemsis from s. marmolepis snlely un the size of the seales, which he gives as $3 .-38$ about the bouly in s. grandisquamis. 46-48 in S. monensis. In the series liom Purto Rien under emesileration the variation is as follows:

Stales about the holy...........

Nimber of specimens........... $\quad$ \& $:$ i $\quad$ i li

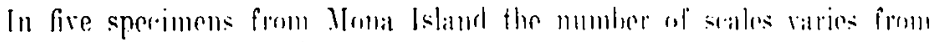

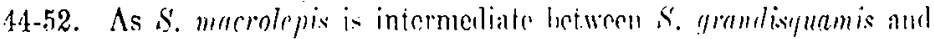
s. monensis. it is covdent that the varation in the pesent series indules all three supposed forms. 'There is probably a some what difirent range of variation on the several islands, but the extremes are certainly included in that of the Porto Rican series. Reproducer tails have a mulv widened series of uncrian rentral scales.

An ego, probably of this specie's. was fumbl muler a long at dibonitu. Angust 21, 1919. It is white, discololed be stains. will a hard ant surouth sholl. o $\times 1.5 \mathrm{~mm}$.

\section{Anolis Daudin}

\section{Anolis cuvieri M[er'm}

Eleven specimens of this speries were collectert at dilumitn. Inolis

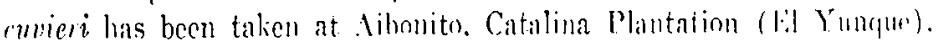
Humacar, Luquillo, Maragrucz. and Ttuado. It is probahly mot foumd in

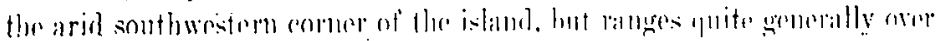

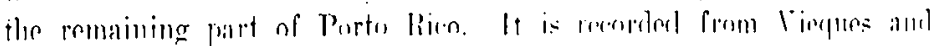




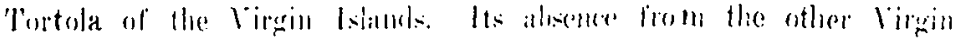

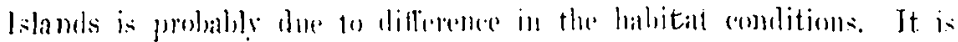

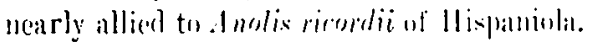

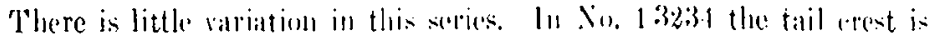

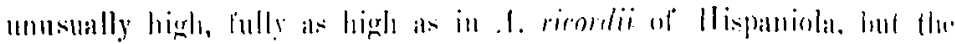

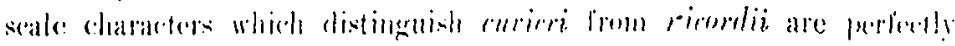
(onstant.

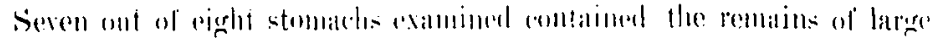

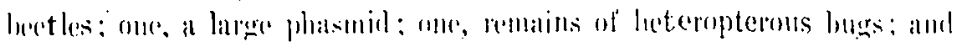

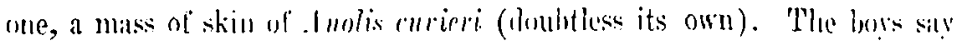

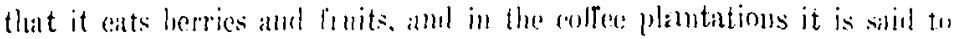

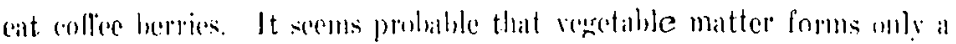
small proportion of its ford. as in . luolix cristalellus.

\section{Anolis cristatellus l)umeril and Bihron}

'The following lowilities are representer by three humbed specimens in the collection: Alljuntas, Aibonibu. Balyanon, Catano, Coamo Springs.

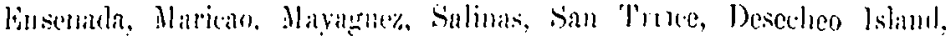

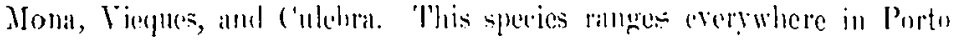

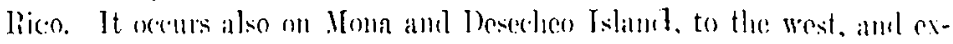
temes through the entire Yirgin group to the enst. I lo not regand the

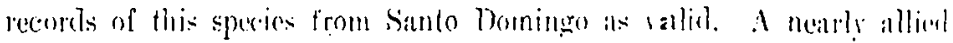

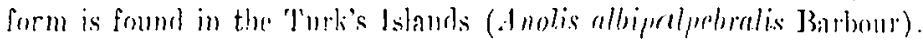

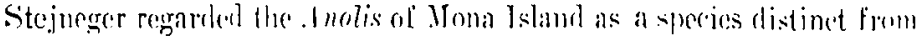

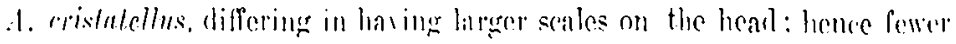

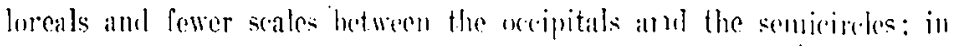

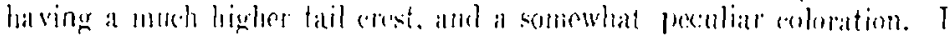

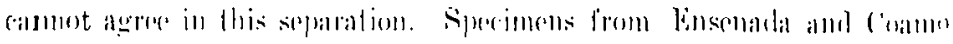

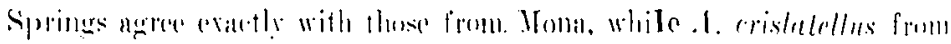

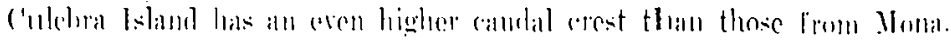

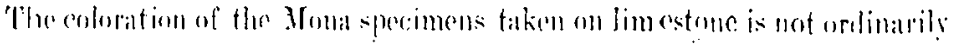

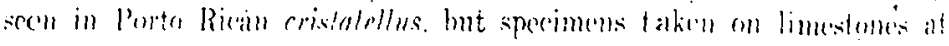

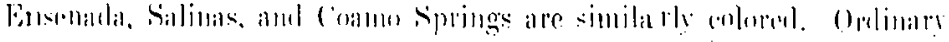

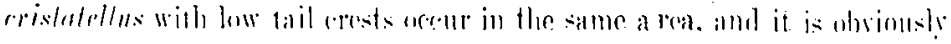
impossible to separate them. "Tlue speries deos difler somewhat on the

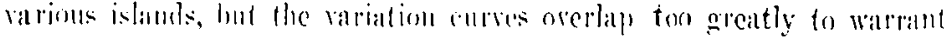

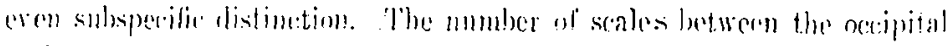

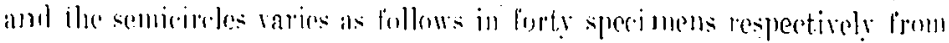
Yierplues and Mona Islands: 


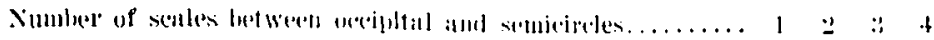

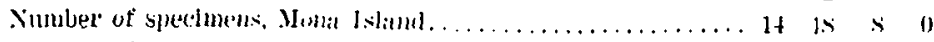

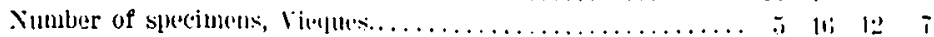

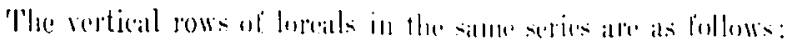

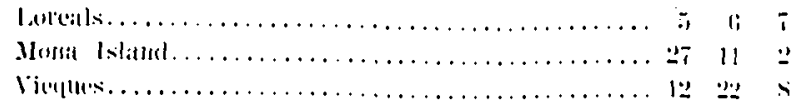

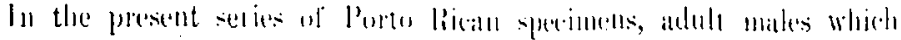

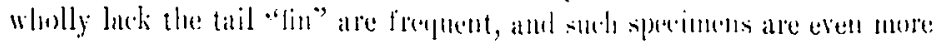

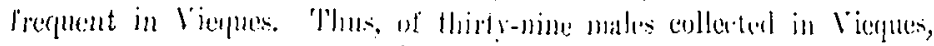
nome halve a high continuous "fin" like fluse of ('ulebla or Mona, twentyseren have a low serraterl cerest, about one-third ats high as the diameter

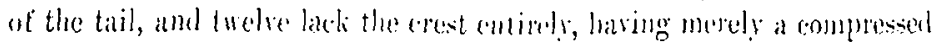
tail with a denticulate row ol clorsal seales. This is aridently the con-

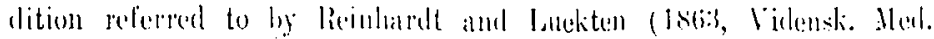

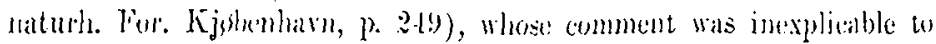

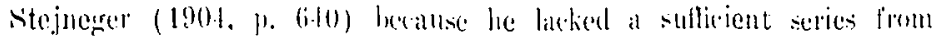

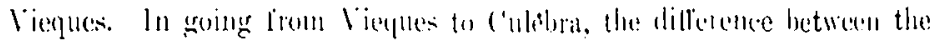
tail erests of the males is rery striking, and if they were not linkenl by

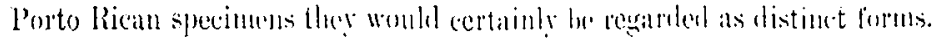

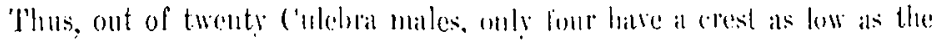

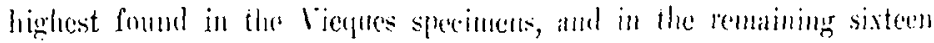
it varies from a height equal to the rertical diameter of the tail to twien the diancter. Fidenty we have an exerlent example of the begiming

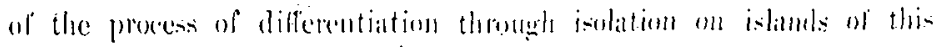

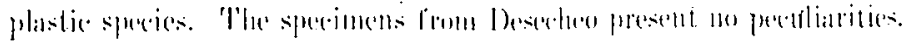

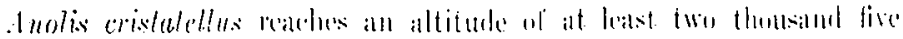

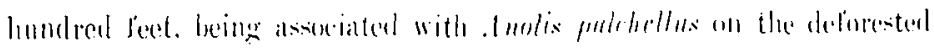

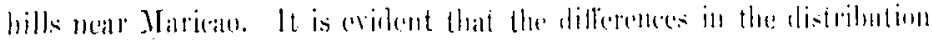

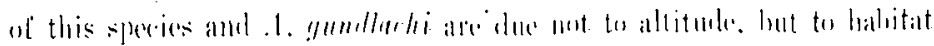

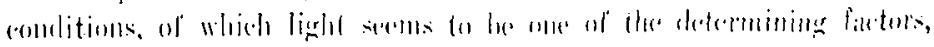

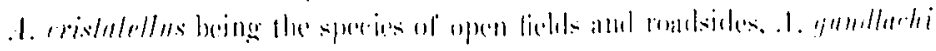

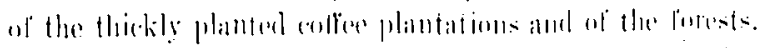

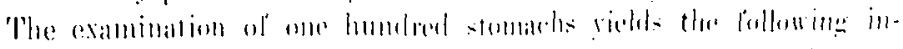

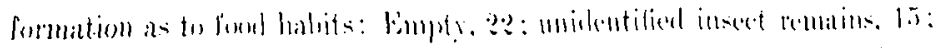

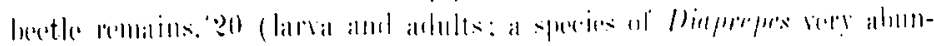

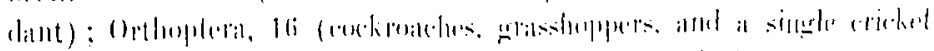

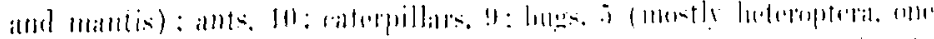

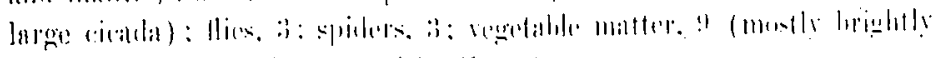

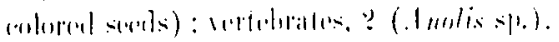




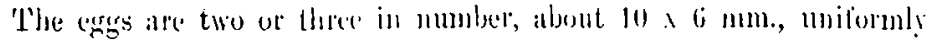
oval, the surface white and striate. 'They are freguently found under. the edges of logs or stones, or in debris about the base of banana plants.

\section{Anolis gundlachi l'eter's}

Forty-ement specimens ol this species were collected at the following localitics: Adjuntas, Aibunito, Maricau, and lil luncue. This species is very distinct fom . I. cristatellus, but is obrionsly directly relatiel in that species. Its range and habitat are much more restricted and the anount of variation is according!y smaller. In the present seriter the heright of the tail crest (at its highest point) reaches a muxiuumu uf three times the diameter of the tail at the same joint.

\section{Anolis stratulus Cope}

'l'he following localitics are represented by lilly-eight specimens of this

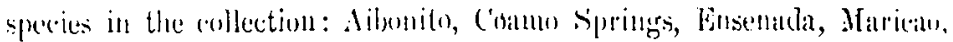

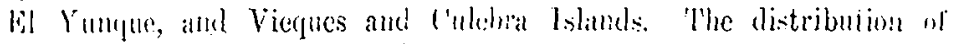

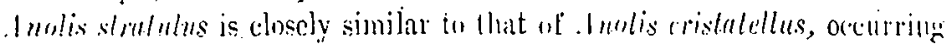

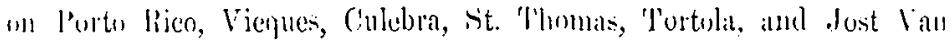

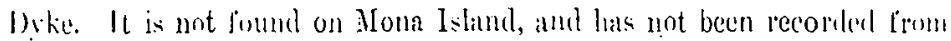
St. ('roix, where it migght logrically ise expecterl to occur.

The series under examination shows only slight wariation. The majurity of specimens have the supranoular semiciredes in contact. (1me. (No. 1:19.2) has only a single row of scales between the necipital and the semicireles. In recently halched sperimens the clorsal marlings are invariably indistinct.

The coamination of twonti-five stomaths imlirates that anti lorm a

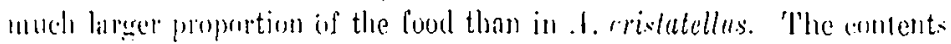
are clasified an follows: limptr, 3 : midentiliable insed rentains, 4 : ant

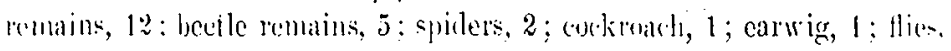
1 : lizard siin (loubtless its own), 1.

\section{Anolis evermanni Stejueger}

The following localities are represonted by thirty-scren specimens in the collection: Adjuntas, Milonito, Mariean, and El Yuncue. Thio species is comfined to l'orto lico and does sunt appear to be especially related to the green Inotion of IJispaniola (A. holorocyanus). It appears

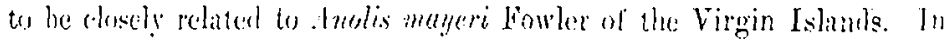

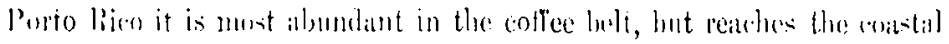

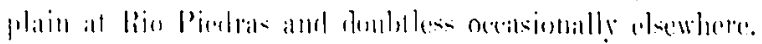


As in 1 . stralulus, the scale between the supraciliaries und the supraorbital semicircles, anterior to the supratorbital granules, is remarkably constant. It is double on one side in only one specimen ont of thirty-one examined. The semicircles may be broadly in contact (3 specimens), narrowly in contact (9), or separated by a single row of scales (19). The scales between the semicircles and the oceipital valy from two to luar.

Anolis mayeri from the Virgin Islands was compared in the original description with Anolis cuvieri and Lnolis eristatellus (l'owler', 1918, Papers Dept. Marine Biol., ('armegie Inst., XIT, y. s, Figr. t), chiefly because of the presente of small gramulan seales interspersed between the larger dorsal scales. On examination with suflicient magnification, botl A. cristatellus and A. ecermanni prove to exhibit this character. A. mayeri is thercfore not particularly related to 1 . curveri and is in lact intermediate between A. cristalellus and A. exermenni, having the two

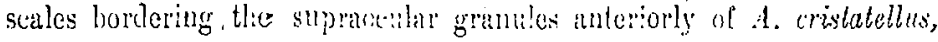
while it is closely allied lo .l. cermanni by its labitus (especially the form of the head and tail), the larger s(ales, and the unilormi (green) coluration. It is remalliable that no other specimens of this species hatre appeared in the numacous collections from the Virgin Islands.

'The results of the exaniuation of the contents of twenty stomachs are as follows: Empty, 3 ; bectle remains, $11:$ ways, 2 ; ants, 1 ; caterpillars, 1; spiders, 1; skin of Anolis (doublews its own), 2; juvenile Inolis encrmanni, 1 .

\section{Anolis pulchellus Dumiryil and Bibrom}

The Pollowing localities are represented by eighty-seven specimens in the collertion: Aibonito, Catano, Coamo Spprings, Ensenala. Marian, Jayaguez, San 'Turee, Culebra and Vienpues Islands.

Anolis pulchellus is recorded from nearly all of the lirgin fslands, in-

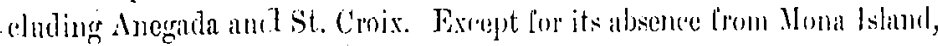

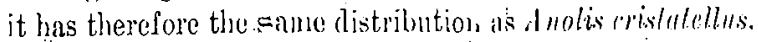

The number of loreal seales in a vertical row is usually four (live or six in at. hrugi); in eighty-fle specinens. sixty-nine have lour loreal rows, filtecn have five and one has six. The scales semanting the occipital from the supraorbital semicireles number one in one specimen, iwo in twenty-nine specimens, three in fifty-one, and four in loml. 'The semicircles are in contact in seventen specimens, separated ly one scale row in sixty-six, and by two sceile rows in two.

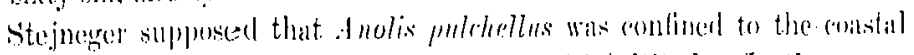

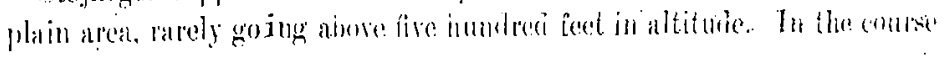




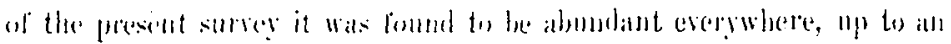

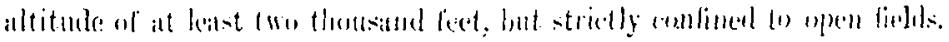

\section{Anolis krugi Potris}

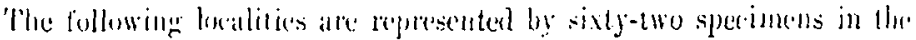

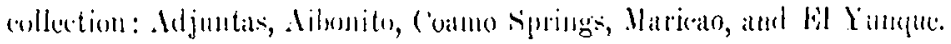

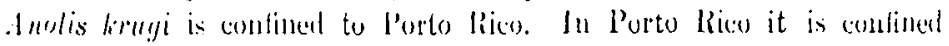
liargely to the coffee belt, extending beyonel it only where similar habitat romelitions occur. It is directly related to the mere widely distributed

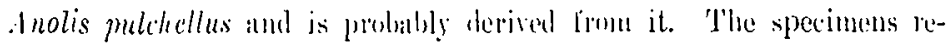
corted from (illania by fowler (1!)1s, l'aper's Dept. Marine Binl.,

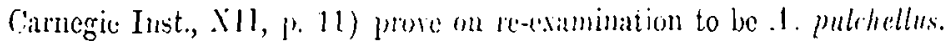

In sixty specineme, the number of loreal scales in a rertical rom is four in one sprecinen, five in thirty-four, six in twenty-threc, and scren in two. The mulser of seales helween the uceipital and the supranditial semicircles valies lrom one to six-one in one specimen, two in eiglteen. three in twenty-live, loul in thisteen, five in two, and sis in one. 'l'he: supmorlatil semicireles are in contilet in two specintens, separated by al single seale fow in thirty-lour, by two scales rows in nineteen, and ly.

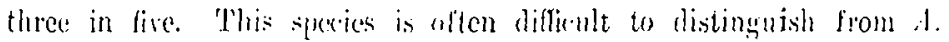
julchellus without direct comprarisons; the colore of the dewap in life,

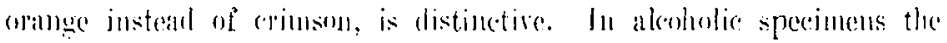

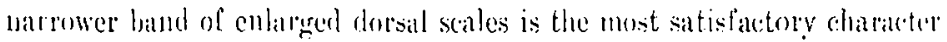
for separating the two. Other characters are at hest comparative, uselul ail]y Cor a series of specinems.

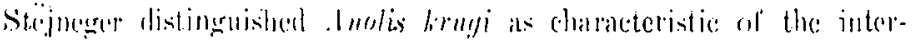

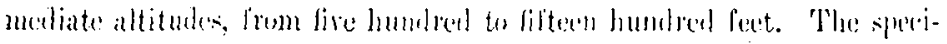

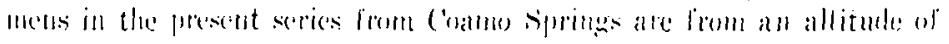

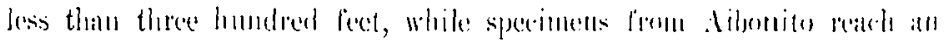

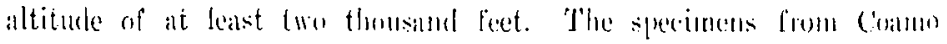
springs supply the elue to the determining latetor in the dislribution of

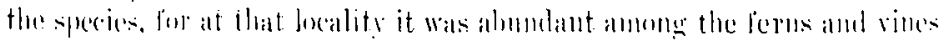

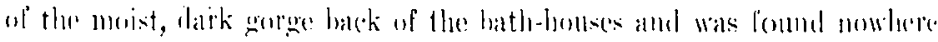

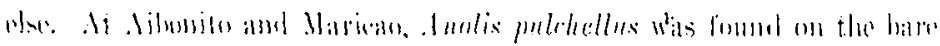

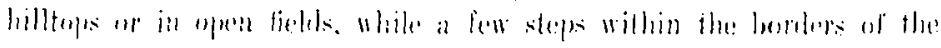

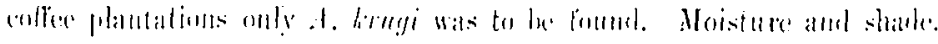

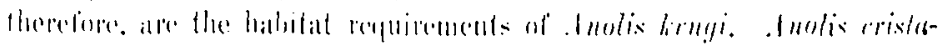

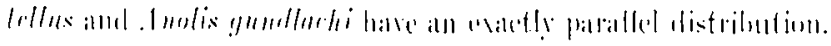




\section{Anolis pencensis St}

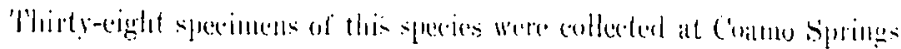

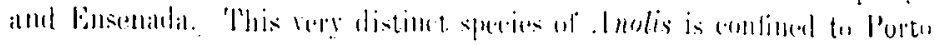

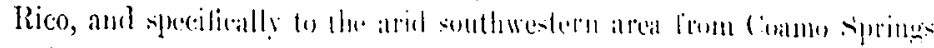

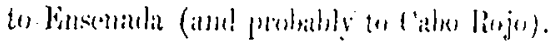

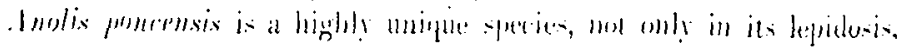

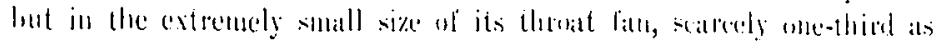

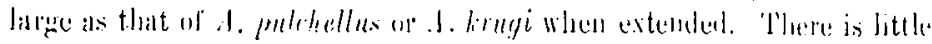

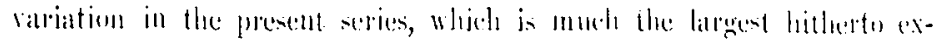

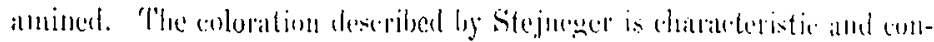

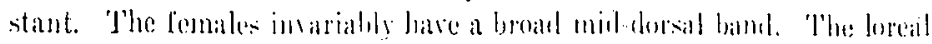
rows in a renteal line are thee in cighteen sperinems, lour in twents.

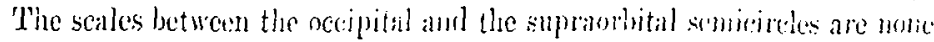
in two specimens, one in twonty-one, and two in fourtere. The scale mus

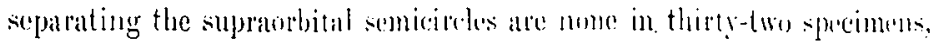

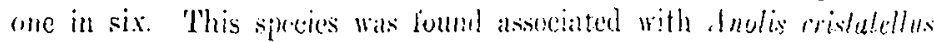

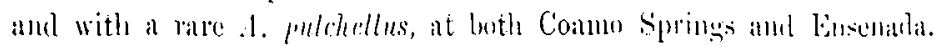

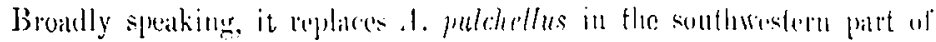

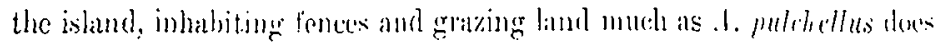
in the remaining part of the istant. A few specimons were londul on the

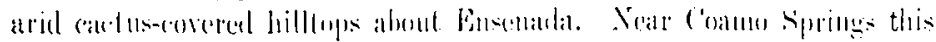

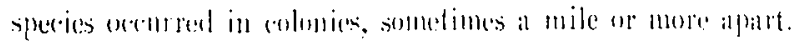

\section{Cyclura liatlin}

\section{Cyclura stejnegeri barbmur amb Nibble:}

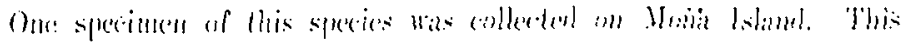

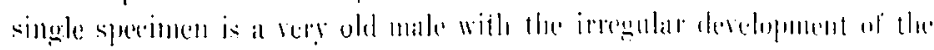

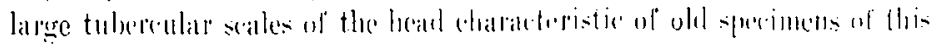

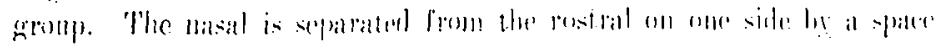

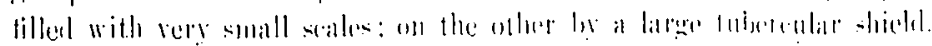

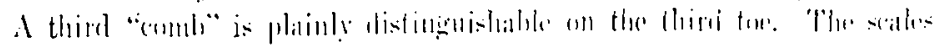

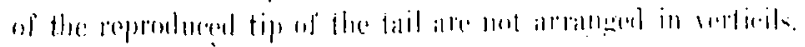

The suritsmencinents ats at bollows:

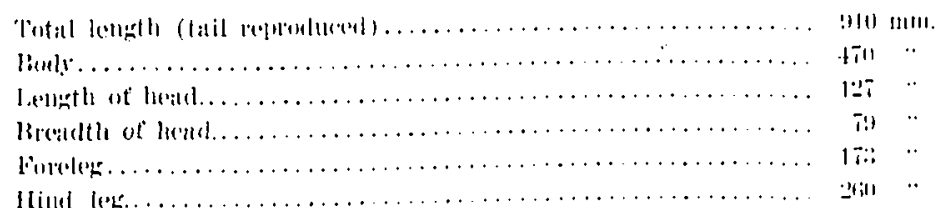


In spite of the sepporation of the nasal shield froun the fostral, I have retained the name slejuergri, as it mily well he the ase that the joung of the three related specics, cornula, niycrrima, and stejnegeri, are well distanguishable, while in the adults the chalacters are obscored. In other respects it arrorts well with the previonsly describer specimens from

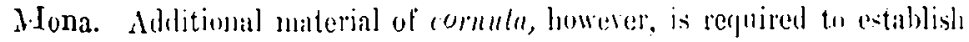

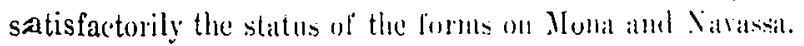

\section{Celestus Cira!}

\section{Celestus pleii (1)uncril and Bibron)}

Seven specimens were collected at dibonito. 'This species is contined to Porto Rico, where it is apparently ram and of local distribution.

The present series is so miform in sule chararters as to sugrest that they are disectly related. 'f'he propertion of the length of the forelimul to that of the body varies between $12: 100$ and $15: 100$. 'I'be stales aluout. the body ane 34 in one, 35 in one, 36 in fonte, and 35 in onle.

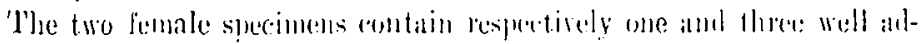
vancel (mblyos. The egrog measures 18 x 11 mm. The completely

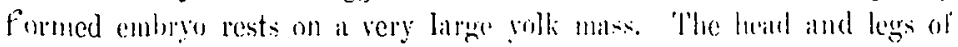
the embrgo are proportionately larger that in the astall, while the tail is shorter.

\section{Ameiva Meyer \\ Ameiva exsul Cope}

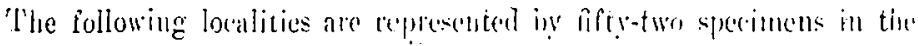

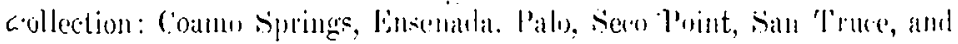

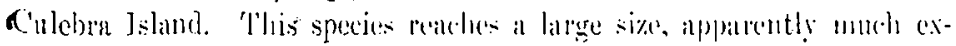
aecding hall a meter, but the larger specimens ale exceptionally wary and

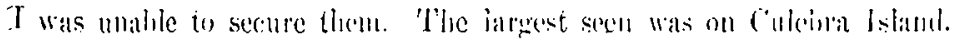
Tu nearly all the specinnens examined au additional row ol ventribl plates. mol cach side is enlatered to a varying dewree. in some cases to such an extent that there are olistinctly twelve longiturlinal rows of ventrals.

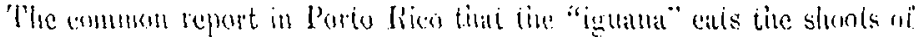
young corn alprears to be supporterl to a legrec by an cxamination of stomach contents. (If twenty stomaths examinerl, one was empty : eleven

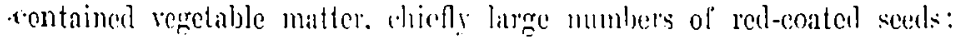
fre, unicentifiable insect remains: iwro, crickets; thee, smali crabs: three.

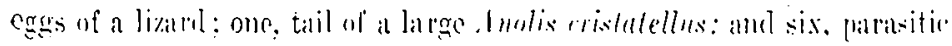
worms. 


\section{Ameiva alboguttata Boulenger}

Fonty-two specimens were collected on Mrona Island. 'l'his species is confined to Mrona Island, where it is abmulant on the low terrate to the west and soutl.

Ameira albogullala is extremely relese to dmeiva easul, but mily he

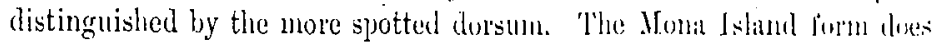
not exhibit the tendency to enlargenenit of inl inditional low ol rentral plates, one specimen having only eight longitulinal rows ofl rentrals (. ou. $13739)$.

'The results of the examination of twenty stomalds ande ats follows:

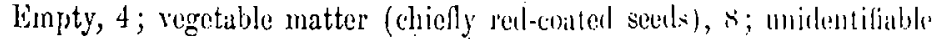
insect remains, 3 ; beetles, 3 ; cricliets, $2 ;$ land snails, 2 ; Inolis crishtellus (juv.), 1.

\section{Ameiva wetmorei Stejnęgrer}

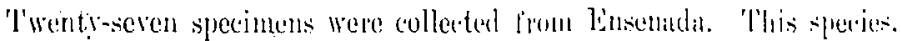

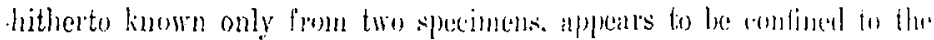

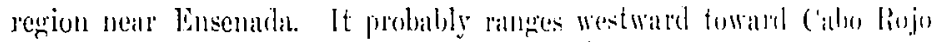

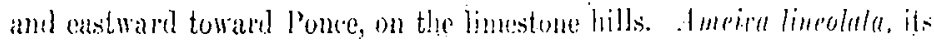
relative in Hispaniola, appeats to be similarly confined to the mure andid parts of that istand, and ariel or seminarid conditions prevail also on Great Inagua and st. Crois, each of which is inhabiter by a related species, 'l'hese four' species lum a highly interesting gronp of Ameivas. (haraderized by the oblicue seales of the tail, a distinctive habitus, and a lineolate type of coloralion.

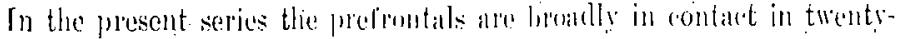

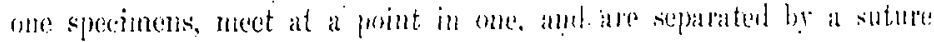
between the frontal and frontumatial in three. The number al sulumciliaries raries from five to seren: ammally six. The interpalrietil is

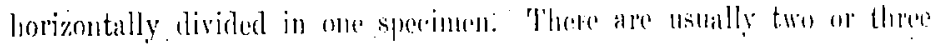

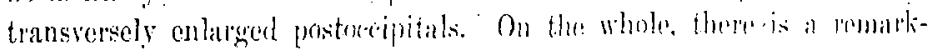
ably small degree of variation.

the measulerments of a male and female spmeimen are:

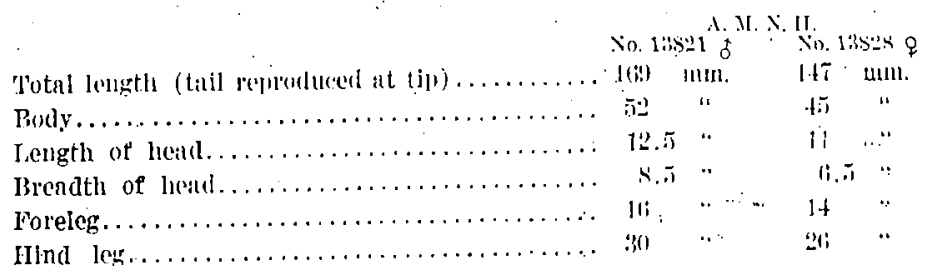




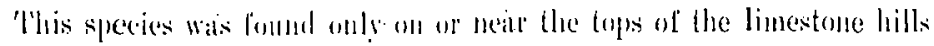

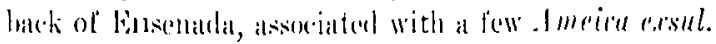

\section{Amphisbæna Limué}

\section{Amphisbæna cæca Curiel}

Eighteen sperinens of this speries wee collected at Ailonito, Bayamon, and Rio Piedras. 'l'his spereses is confined to Porto lico, with a related soecies in the Virgrin Islands (.1. fromes/rala) and another in Hispaniola (.1. manni).

'l'he variation in the present sories falls well within the limits estat)lished by Stejneger. Ono sperimen lats a small supracular plate on each side. When killed in formalin, the load is bent abruptly to one side, indicating apparcently a specinl derelopment of the muscles of the neck, which doubtless is of allantage to the animal in burrowing. 'Tlhe laregest. sperimon measures 2333 num.; : tail, 18 !n!m.

All of the specinens were foum burrowing in the ground, most of them uncoverel by cultivation. One was founil about three inches be-

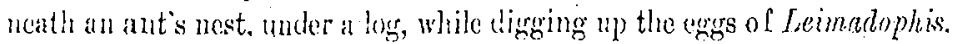
'J'hree egars were foumb-one beneath a termite nest, the ot ler two under the log where the above-mentioned alult was dug up. T'he largest egor mensured $42 \times 11 \mathrm{~mm}$.

\section{Mabuya I'itinger}

\section{Mabuya sloanii (Dandiri)}

The following localitios are represented by seven specimens in the eolleetion: Irayamon, Fonsenada, and Iona ame ('ulebra Jslands. This

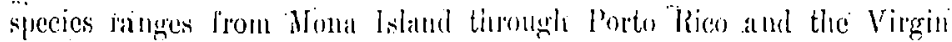
Islands. Barbour (1916, p. 219) refer's two specinens Irom 'Turli's Istamt, in the souther'n Bahamas, to this species, and it secms proballe: that the $2 / a b u y$ of Il ispantiola is also referable to the same species.

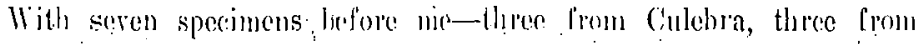

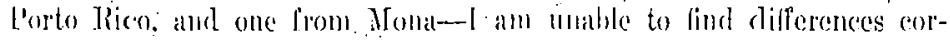
responding to the scparates mealities, other thatu the difference in color

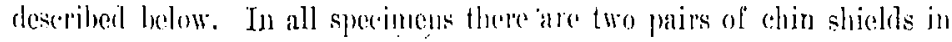
contace belinel the unperied postmental. The prefrontals are narrowly or widely sepalated by a sulure between the frontal and the lrontonasil.

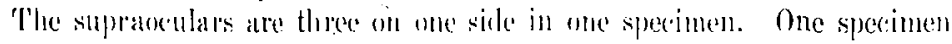

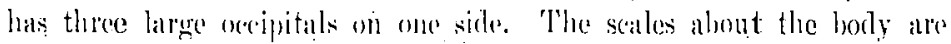

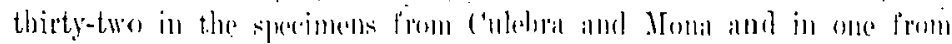

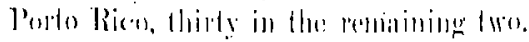


'The coloration is highly interesting. The three specimens from Porto Rico agree with the dexcription of Stejneger (1901, p. 611) in the presence of a narrow balck border above the dorsolateral ligrlit line. In the specinens from ('uleblat this is increased anterionly to indede the whole of the hearl, nexk, anil shoulders, leaving. howerer, a sharply befines median light line from the frontal to the slomlders, where it moreses into the dorsal colol'. 'Phis pattem is approsimater also in the speremen from

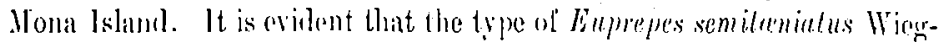

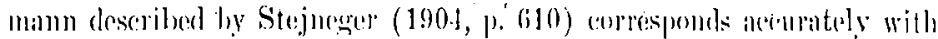

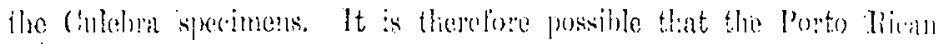
form may be sufficiently distinguishable to merit specific or subspecific idesignation, in which casce slomia would be restricted to the form in the Virgin Tslands (including Viegues and Culdera) and 11. nitide Carman woukl he applicable to iloe l'orto lican and Santo Inomingan lorm. In

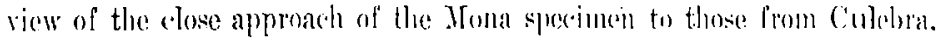
I prefer to relain, for the present, the use al stomii for the contive series.

'The measurements of the only specimen with a complete tail are as follows:

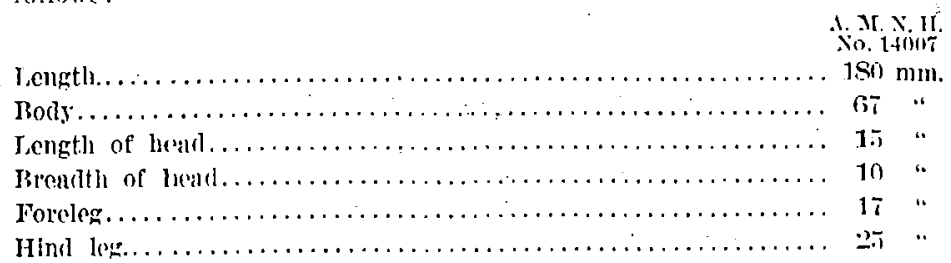

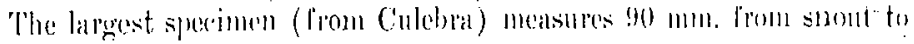
rent.

\section{Typhlops Oppel}

\section{Typhlops richardii 1)umiril and Bjibron}

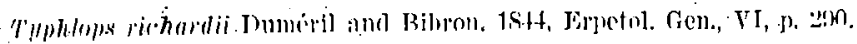

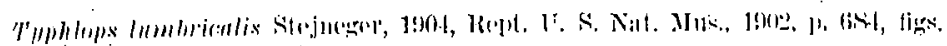
1+1-1+t.t.

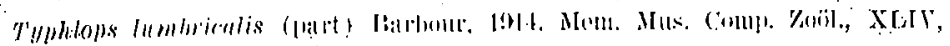
p. $: 322$.

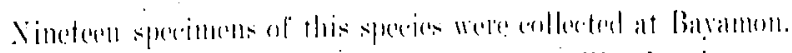

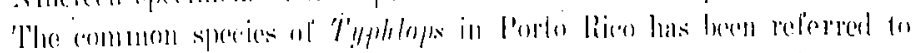

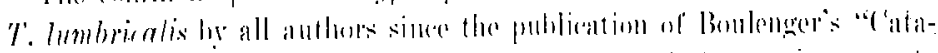

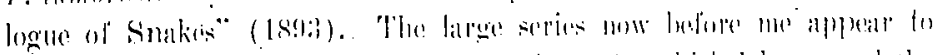

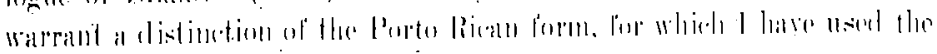


name applied by Duméril and Bibron to the Typhlops from St. 'I'homas, on the ground that it is logically likely to he conspecific with the Porto Rican form. In its more elongate form and greater number of scales from snout to vent, the description of $T$. richardii applies fairly well to the series from Porto Rico. Typhlops humbriralis is reported [rom all of the Greater Antilles and from a large number of the lesser Antilles. Being unable to examine specimeus lrom the Lesser Antilles, 1 am ullible to form an opinion as to the status of the forin found there. 'The Limnean description of T. lumbricalis is said by Dumeril and Bibron to be taken from the Jamaican Amphisucena argenta of Browne. Not having Jamaican specimens for comparison, l have compared the Porto Rican series with the spccimens from Cuba in The American Mfuseum of Natural History.

In fourtecu specimens examined in detail, the total tengrth varies from 216 to $310 \mathrm{~mm}$.; arerage, $26(i \mathrm{~mm}$. The largest specimen arailable from Cuba measures $2.4 \mathrm{~mm}$., the average lengtl of nine specimens is 203 mm., and the specimen selected by Barbour for cleseription in the "ITerpetology of Cuba" (Barbour and Ramslen, 1919, Mem. Mus. (Conp.

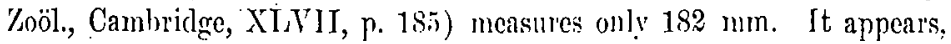
therefore, that the Porto Riean and ('uhan Typhlops a re distinetly differont in adult size. The matio of the borly dianeter to total length is only slightly rifferent in the two series, 34 to 14 in the Porto Rican, 28 to 38 in C'uban. The number of seales about the body is $22-20-20$ in seven speimens, 22-20-1s in sevem, in the Porto Risan serics; the reduction to 20 scale rows occurringr only a little anterior to the middle of the body. In the Cuban scries the scenle formula is 20-20)-18 in six, 20-18-18 in three specimens. The number of seales counted on the mid-dorsal line from snout to tail spine ranges from 365 to 4.15 in the Porto Rican specimens and from $2 \times 0$ to 325 in the Cuban. (The Cuban specimen described ly Barbnur las been reëxamined at iny request hy Mr. Emmett R. Dunn and is . fomm to have botween 320 and 225 seales on the mirldorsal line.) In spite of the relatively sonall series of (uban specimens

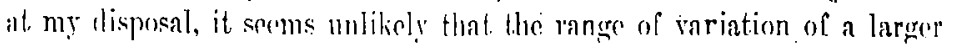
number would be greatly rlifierent.

The Porto Riean specimens are clarker in color, and, with a single excoption, the tail is marked with a white ring. In the specimen describul. ly Stejneger $(1907$, p. 685), as well as in the exception here noted, the white rentral color forms a prominent notch on the side of the tail, inclientiner the existenee of the tendeney to form a ring. No such noteh or ring is fouml in Santo Domingan or ('uban specimens. 
The differences, then, between the Poito Rican and the Cuban I'ylhlops may be summarized as follows:

\begin{tabular}{|c|c|c|}
\hline ' & I'orto Ricnn & Cuban \\
\hline elage Ic & (ireatci thun $2 \pi n$, num. & l.ess than $200 \mathrm{~mm}$. \\
\hline nout to & $365-415$ & $270-325$ \\
\hline & $\begin{array}{l}\text { With white ring ol' } \\
\text { notch }\end{array}$ & $\begin{array}{l}\text { Without white ring } \\
\text { or notch }\end{array}$ \\
\hline
\end{tabular}

The specimens of the present series were found during enllivation on the farm of Mr. B. A. Wall. 'The singre specinen secured by me personally was burrowing in the loose earth around an old stump, in which both Typhlops and Leimetlophis egrgs were found.

'Three eggs of this species were found in the soil about the same stump. contnining well-aleroloped embryos. The orge is elongatert, like a slightly bent eylinder with rounded ends, with a perfectly smonth, white surfaee. The embryo measures 98 um. in length and $3 \mathrm{~mm}$. in diameter. The smallest hatched specimens found measure 114 mm.

'Three of the smallest specimens in the colloction are in crery way like the adults, cxrept that they are pale grayish white. 'This appears ou examination to be caused hy the opacity of the skin, which is nearly read! to be sher, probably for the first time. An arlult ('uban speceimen in the

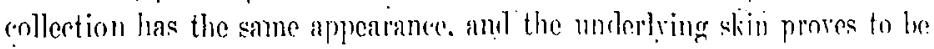

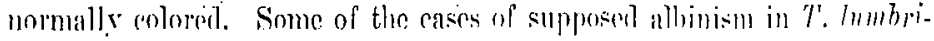
ralis may be lue to this appearanee.

\section{Typhlops rostellatus Stejinewer}

Fileren speeimens of this species were collected at $\Lambda$ ibonito and Bayamon. This species is confined to Porto Rico, where it proves to he widely distributerl.

It is readily distinguished from $I$. lumbriculis by its nearly uniform coloration above and helow and the sharply dedinerl white sulomalal spot.

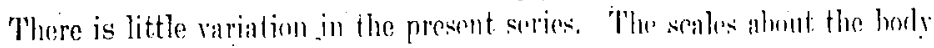
mumber twenty ju ten sperimens, orighteen in one.

The masurements of the larecest spesimero are as follows:

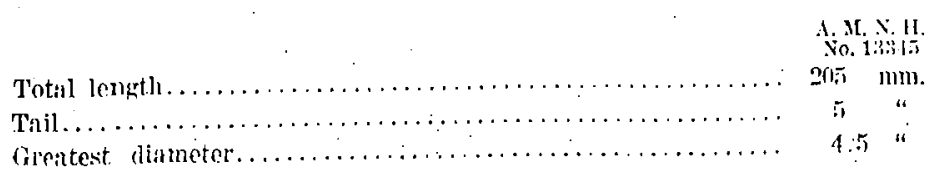




\section{Leimadophis Fitzingen"}

\section{Leimadophis stahli Ste.jnegre'}

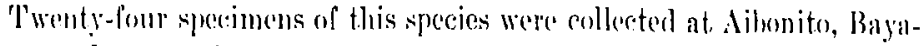

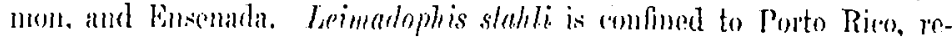

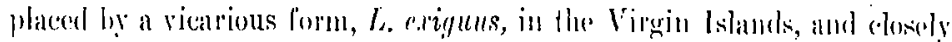
related to the Hispaniolan L. parvifrons.

The range in mumber of ventral plates is slightly areater in this serios than in Stejneger's-1-f(j-160 in twenty-three specinens. The subcaluals range from 83-9\%. The sexes are scarecly distinguishable by these characters. The tail length varies from .29) to . 3 - of the totnl length $(.29-.31$ in $9, .32-.34$ in 8 specinens). The seales about the body are miformly 19-19-1\%. The lower lahials are nine (eight in the original deseription). Freshly hatched specimens show the color pattem most rlistinctly, esperially the merlian black marking on the hear. The largest specimen, a Pemale, measures $580 \mathrm{~mm}$; t tail, $178 \mathrm{~mm}$.

Eggs of this species were found in three places: under a log in a pasture and under an old termite nest in a colfee plantation at Aibonito and in the loose soil uncler a stump at Bayamon. One lot contained seven ergs, one thirteen, and one forty. Six well-developecl exps were found in the adult female staying with the largest number. The eggo in this place were in three lots: cighten old and discolored, in two clusters; six loose, somewhat different in appearance; and two clusters of six and ten eggs rery fresh and white. Wxamination of the egos shower that they contained embryos at at least three stages, the fresher egrgs having scarcely begrum reselopment. the ollest containing embryos nearly ready to hatch. 'The eress found under the termite nest were also in two clusters-one of

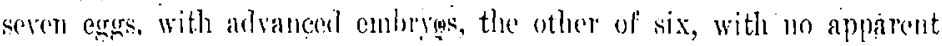
Jerelopment. The older egges are slightly larger, ranging from 21 to 2.5 mom. in length and from 12 to $15 \mathrm{~mm}$. in liameter. T'le surface is funely striate. very whe in the fresher specimens. It appears that the allult lemales of this sueceres take up a lowation from whith they lo inot wainder lan, ane in wheh they lay suressive batehes of egess. from six to eighteren (?) in number. The largest "sest:" contained the remains of still older" russ, which wore cither jufortile or lrom which the youmg had hatehed. The egors aro biat in clusters of six to tem, the indiridual exgs arlheringr

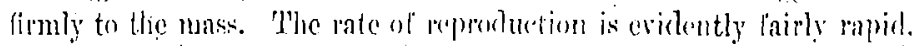




\section{Alsophis Fitzinger \\ Alsophis antillensis (Schlegel)}

1lsophis anegade Rarbour, 1917, Proc. Biol. Soc. Wash., XXX, p. 10!2.

Two specimens were collected at Coamo Springs. This species has not bitherto been recorded from l'orto lico, although there is an older, questionable record from Haiti. Its presence in Porto Rico, togretler with that of Eleutherodactylus anlillensis, diminishes the difference between the Porto Rican fauma and that of the Virgin Islands.

'The identification of these two specimens with this speeies removes the element of geographical distinctness from the allied $A$. porloricensis. The male specinen has only seventeen seale rows, and so might be identified with $A$. portoricensis, were it not that the coloration of both is nearly typieal of $A$. antillersis, while the female has nineteen senle rows at mid-body. In view of the higher number of rentral plates ane the. ristinct coloration, I prefer to retain porloricensis and antillensis as distinct species.

These specimens agree closely in coloration with the color variety described by Barbour from Anegada, and as I in not wish to admit of a rliseontinuous distribution of $A$. anegadler, it seems best to incluile both Porto Rican and Anegadan spereimense with .1. contillowsis.

The measurements and scalc character's are ats follows:

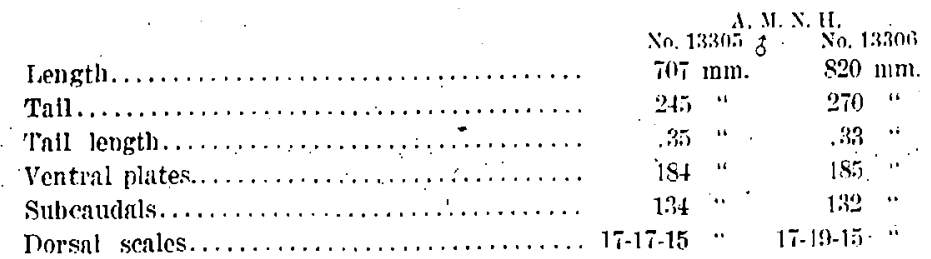

\section{Alsophis portoricensis Reinhardt and Tuetken}

Four speciments of this spercies were colleceted, at Arljuntass and on Mloma

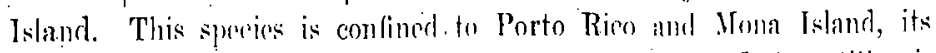
nearest relatives lieing A. melanichme in Mispaniola and .1. antillensis in Porto Rico aml the Virgin Islands.

The two specimens from Adjuntas a perfertly tipical in colubation. the dorsal seales and rentral plates being heavily lomplepen with biack. In the two Mona Island specimens the black is arrangrol as irregrular transcerse markings, not confinerl to the borders of the seales, There does not seem to be any scalo character distinguishing them from typial 
portoricensis. The four specimens fall within the limits of variation establisher by stejueger in every respect. The two from Arljuntas have the dorsal scale formula of $1 \%-1 ;-1.1$ insteal of $1 \%-1 ;-15$, as in thi Mona Island specimens.

The stomach of one of the specimens from Moma contained the remains of two Ameiva alboyullalu and that of the other contained a tail of the same species.

\section{IMTERA'TURE'}

BaBmovi, ThOMas

1914. A contribution to the zoingengriphy of the West Indies, with espectal reference to numplibins and reptiles. Mem. Mus. Comp. Zoïl, XIIV, pu. 200-3in?, l'l. I. text-6ig. 1.

191.5. Recent notes regarding West Indinn reptiles and inmphiblans. Proc. Blol. Soe. Wash., XXYIII. pn, it-78.

1916. Solditional notes on. West Indian reptiles and amphibians. Prous. Biol. Soc. Washl. XXIX, pn. 216-220.

; 1917. Notes on the herpetology of the Virgin Islands. Proc. Riol. Soc. Wash., XXX, pp. $97-104$.

1919. Herpetologicnl notes. Notes on Celrstus, I'roc. New Englnnd Zoöl. Club, VII, pp. 11-13.

1919a. A new roek iguana from l'orto Rico. l'roce. Biol. Soc. Wash., XXXII, pp. 145-148, Pl. I.

Rarbolr, Thomas, and Noble, G. Kivestey

1915. A reviston of the lizards of the genus Ameiva. Bull. Mus. Comp. Zoöl., LX, Ipp. 139-161, I'ls. I-XV.

Fowifik, Hevry W.

1918. Some amphlbians and reptlles from Porto Rico and the Virgin Islands. I'aper's Dept. Marine Biol., Carnegle Inst.. XII, pp. 1-15. PI. I; text-tigs. 1-6.

\section{STEJNEGER, IEONIAARD}

1904. The herpetology of Porto Rico. Rept. U. S. Nat. Mus., 1902, pp. 549-724, Pl. I, text-figs. 1-197.

1913. A new lizard from Porto Rico. Proc. Biol. Soc. Wash., XXVI, pp. $\because 69-72$. 